\title{
THE DISTRIBUTION, CONSERVATION STATUS AND FACTORS AFFECTING THE SURVIVAL OF INDIGENOUS FRESHWATER FISHES IN THE CAPE PROVINCE
}

\author{
I. G. GAIGHER*, K.C.D. HAMMAN and S.C. THORNE \\ Department of Nature and Environmental Conservation \\ Private Bag 5014 \\ Stellenbosch \\ 7600
}

Abstract: Fifteen of the 36 indigenous freshwater fishes of the Cape Province are endemic to this region and a further eight are endemic to the Republic of South Africa. A third of the species are listed in the South African Red Data Book - Fishes. The distribution and conservation status of each species, excluding eels, are described. The possible effect of environmental changes, such as farming and other forms of land use, exotics, mining, industrial development, human settlement and construction of dams, are discussed and conservation measures are proposed.

\section{Introduction}

Rivers of the Cape Province, Republic of South Africa, contain 36 species of indigenous freshwater fishes belonging to eight families and 11 genera (Table 1). The fish fauna is characterized by dominance of cyprinids, mostly of the genus Barbus and by a high degree of endemism. Seventeen species are endemic to the Cape Province, a further five are endemic to the Orange River System, and three more are endemic to South Africa. Conservationwise the Cape Province has a very important freshwater fish fauna because no less than 12 species are listed in the South African Red Data Book on threatened fishes (Skelton 1977).

Most Cape endemics probably evolved in isolation after an early connection with the Orange River System had been broken (Jubb 1964; Gaigher \& Pott 1973). Of the remaining endemics, Galaxias zebratus is of

*Present address: Institute for Environmental Sciences

University of the Orange Free State

Bloemfontein

9300 
marine origin and Sandelia probably populated rivers via connections down the east and southern Cape coast. The Olifants River System, western Cape, is an outstanding example of speciation in isolation. Seven of its nine species are endemic to this single river system.

Barnard (1943), realising the human induced threats to indigenous fishes, initiated surveys of fish distribution. This work was continued after the appointment of an ichthyologist at the Albany Museum in 1962. From 1976-1978 the Cape Department of Nature and Environmental Conservation did a complete systematic survey during which fish were sampled at over 400 different sites covering all river systems (Fig.1). This paper describes part of the results and indicates possible negative human induced influences on fish survival as background to a conservation strategy for Cape freshwater fishes.

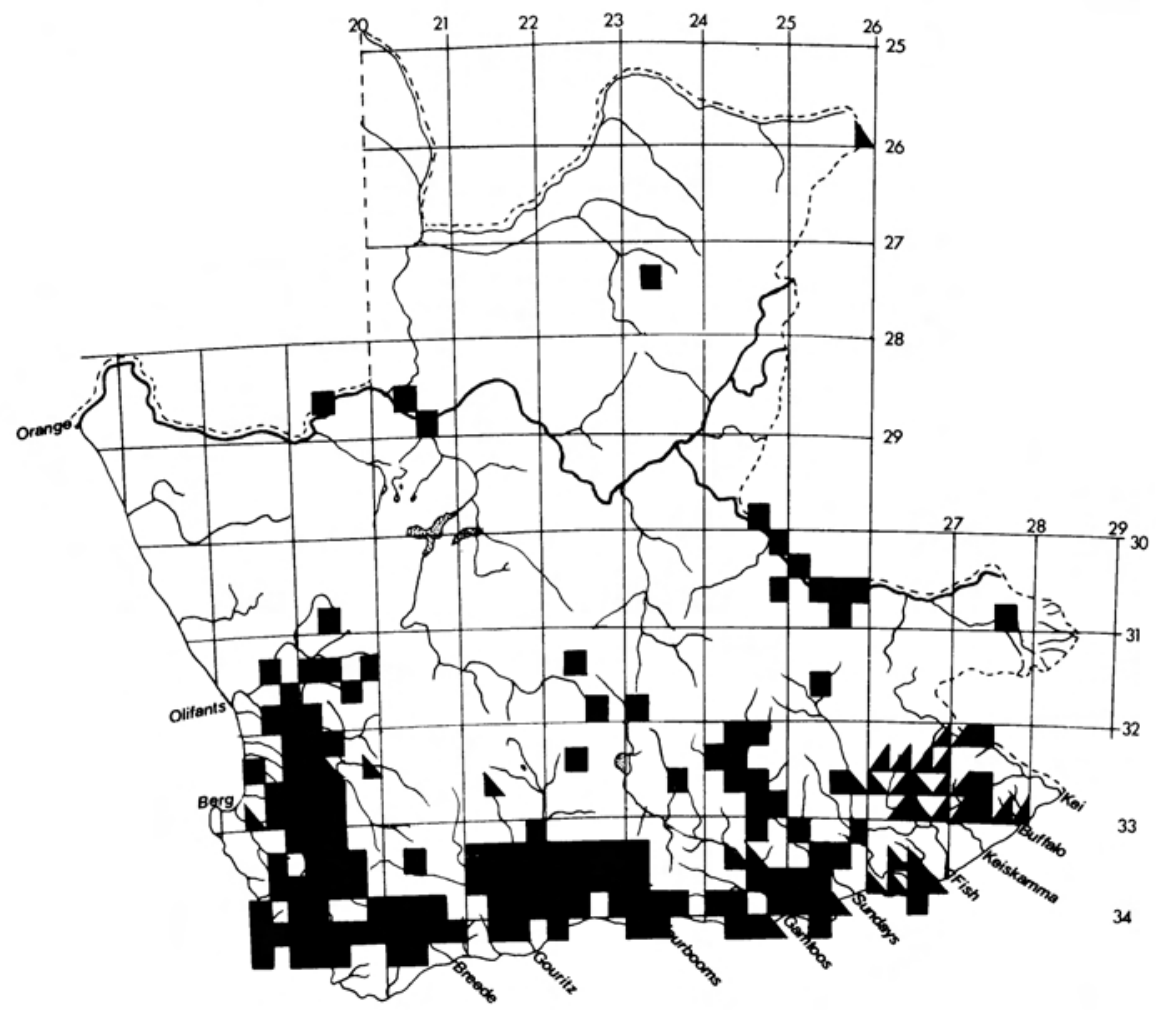

Fig. 1. Quarter degree grid squares sampled by the Cape Department of Nature and Environmental Conservation ( $)$ and the senior author while employed by the University of Fort Hare ( $\mathbf{\Lambda}$ ). Albany museum specimen localities not covered by these squares are also indicated $(\mathbf{L})$. 
For convenience rivers of the Cape Province can be grouped into five regions each with one or more characteristic fish species (Fig. 2). Eels are not considered in this discussion because they are not confined to freshwater and their distribution is adequately described by Jubb (1961). The distribution of each species is illustrated in Figs. 3-34.

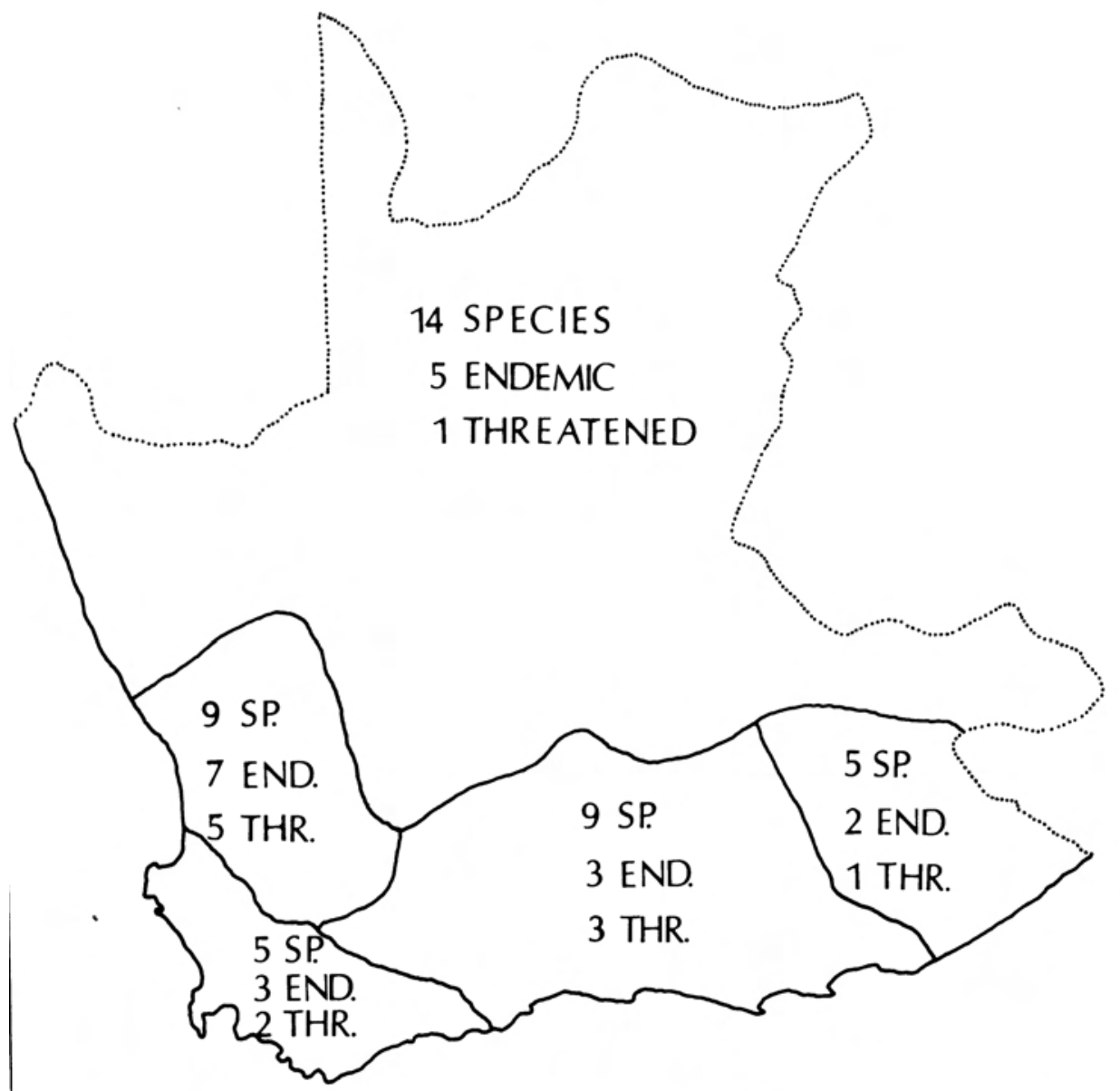

Fig. 2. A map showing the number of species (SP.), number of endemics (END.) and number of threatened (THR.) species of freshwater fishes in five regions in the Cape Province (eels (Anguilla spp.) are excluded).

MAPS DEPICTING FISH DISTRIBUTION IN THE CAPE PROVINCE (FIGS. 3-34) Legend:

-C.P.A. and Albany Museum material records (specimen localities) post - 1967.

A-C.P.A. sight records (recorded localities) post - 1967.

$凶$ - Pre-1968 records, mainly from Barnard (1943).

- Introduced. 


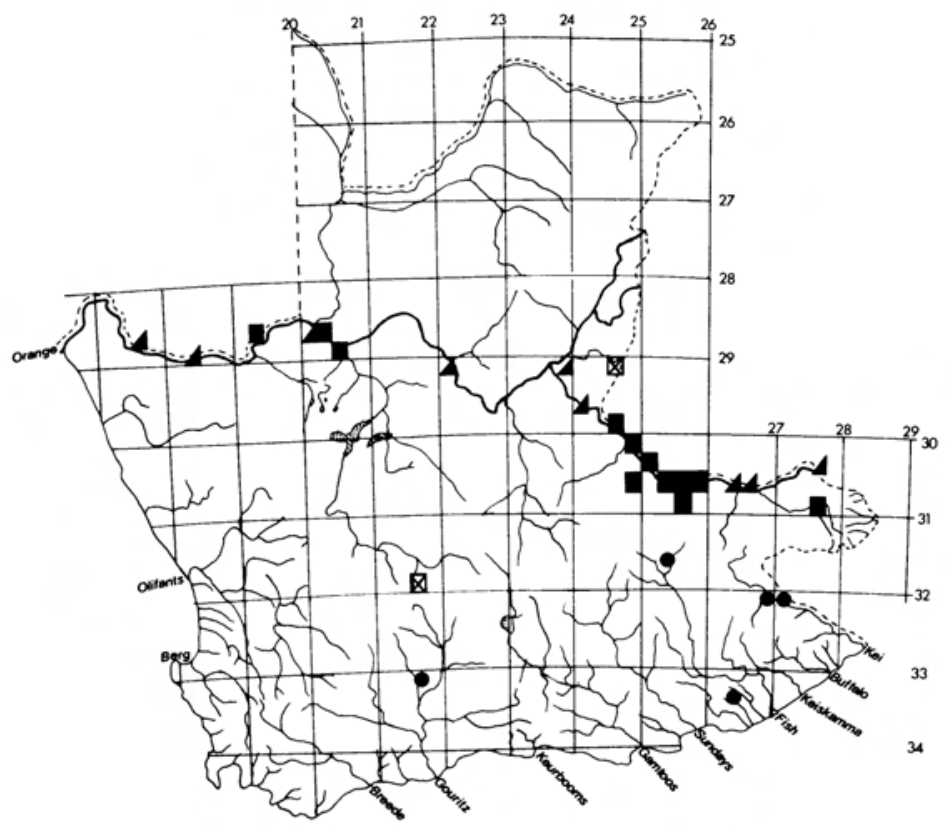

Fig 3. Barbus holubi

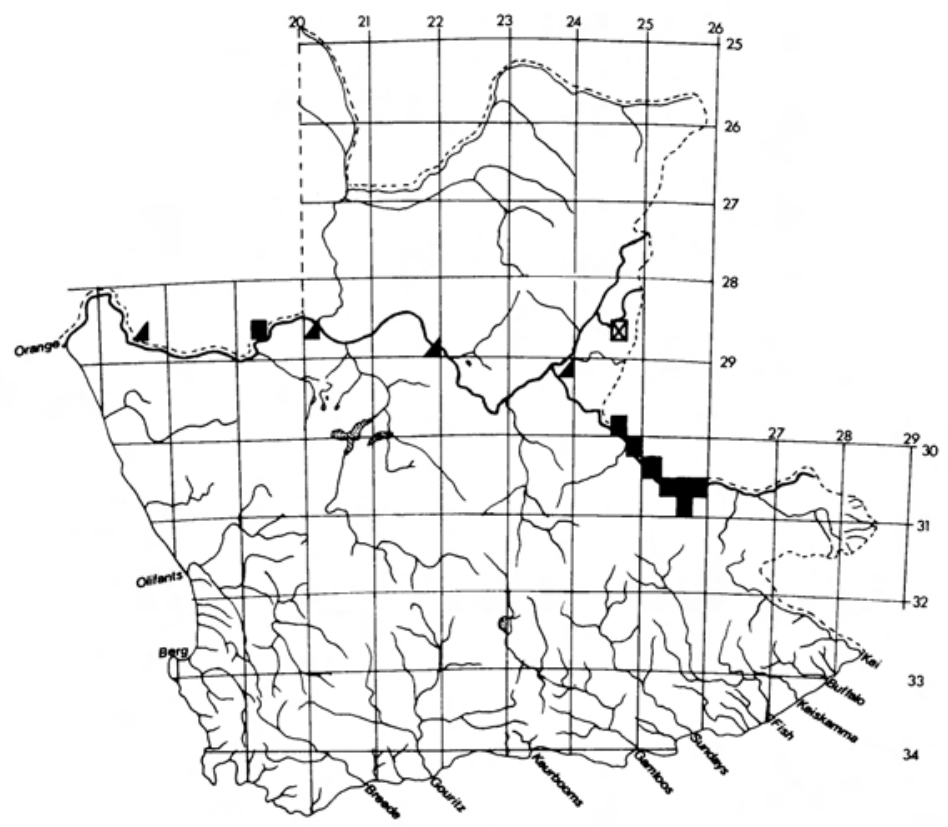

Fig. 4. Barbus kimberleyensis 


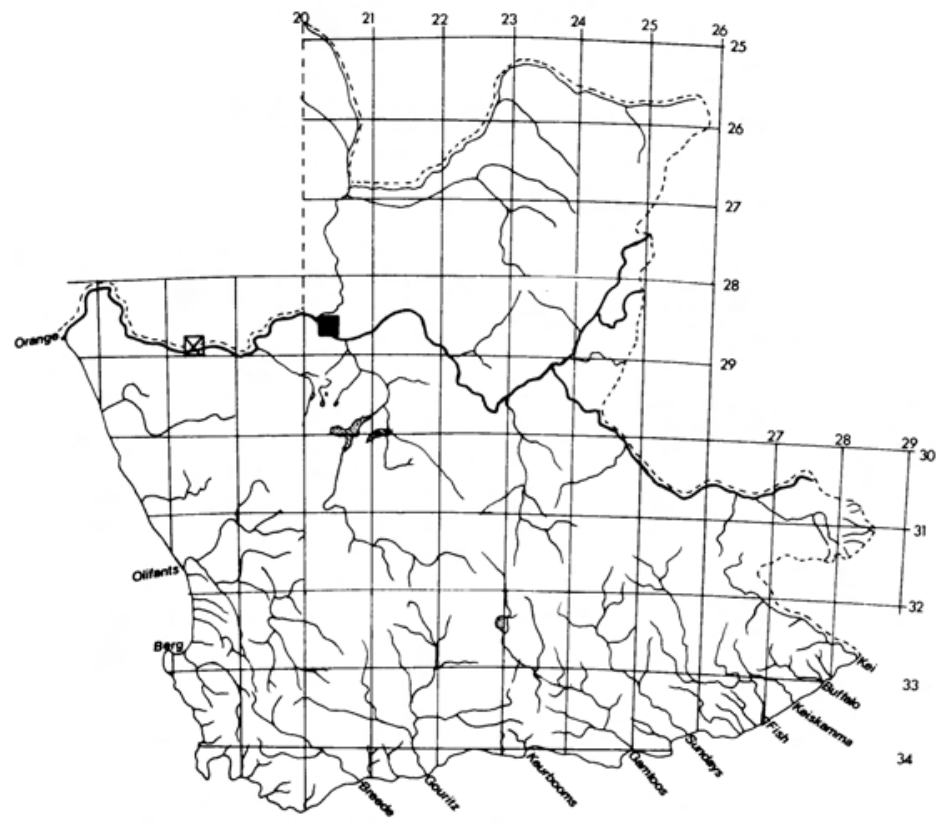

Fig. 5. Barbus hospes

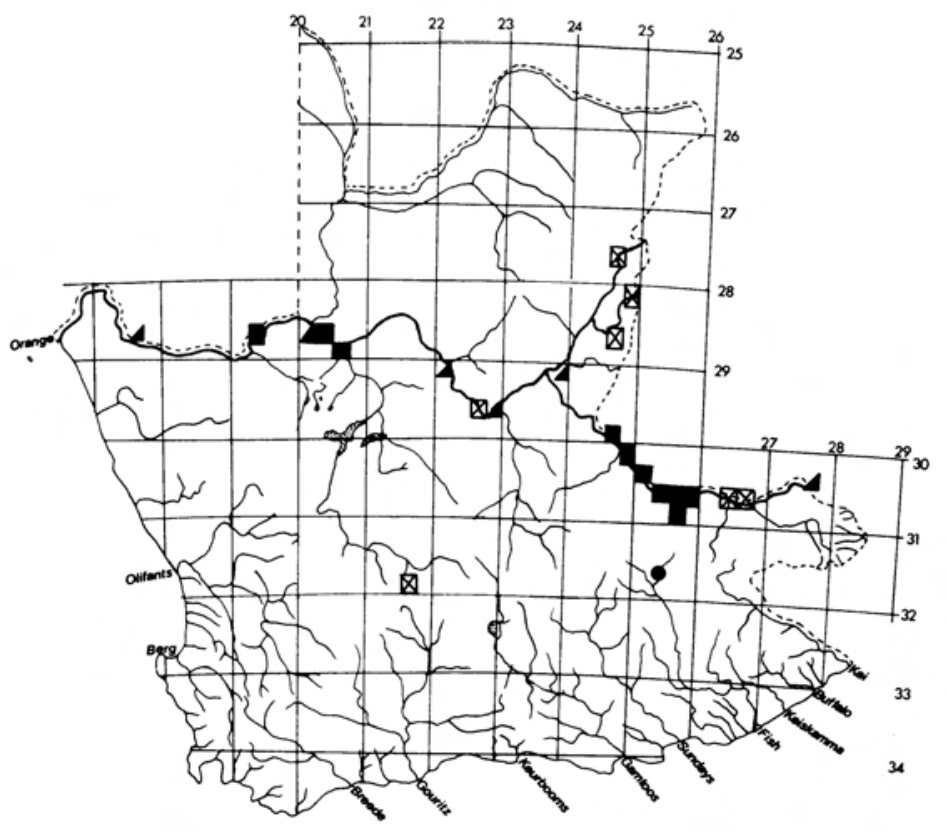

Fig. 6. Labeo capensis 


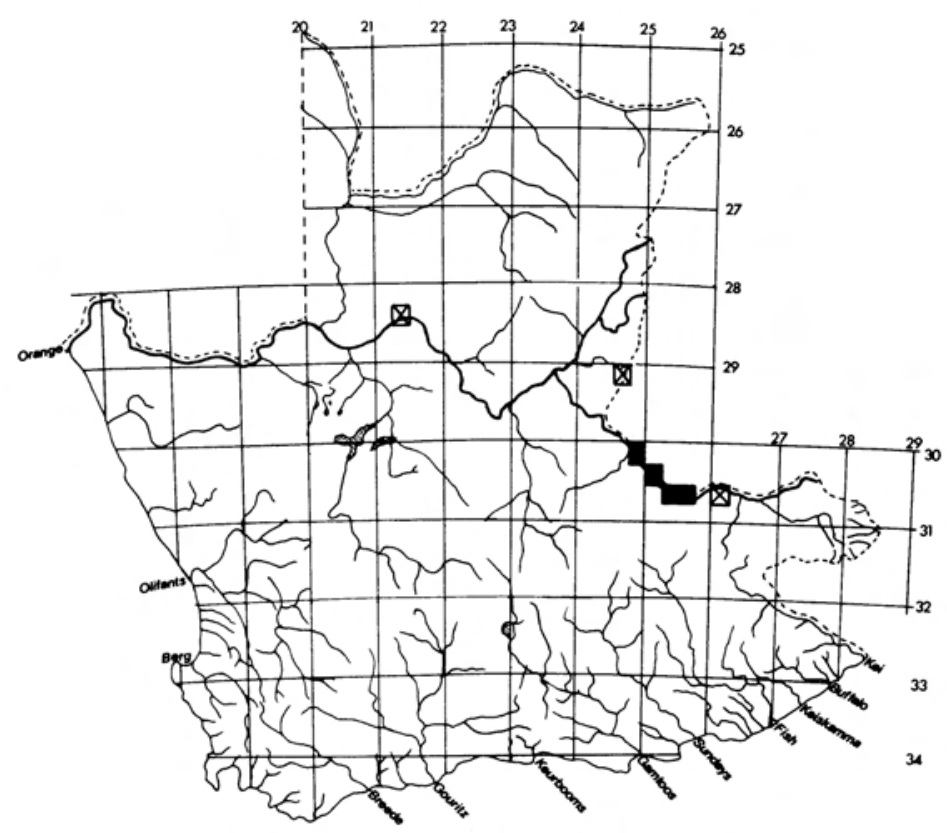

Fig. 7. Gephyroglanis sclateri

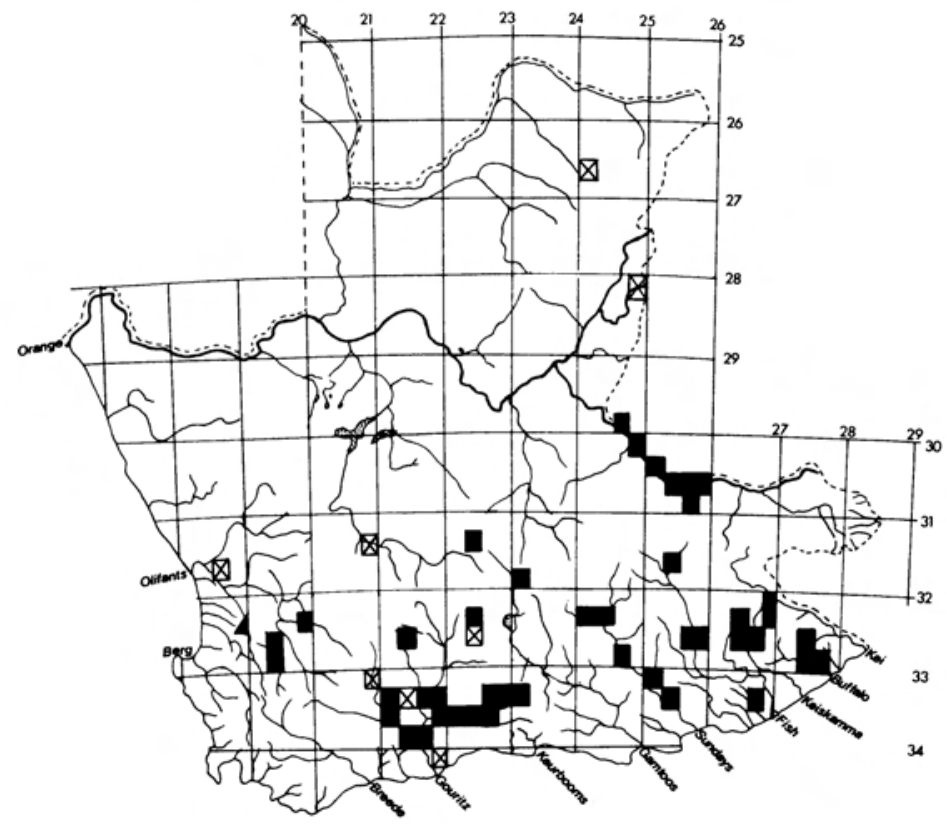

Fig. 8. Barbus anoplus 


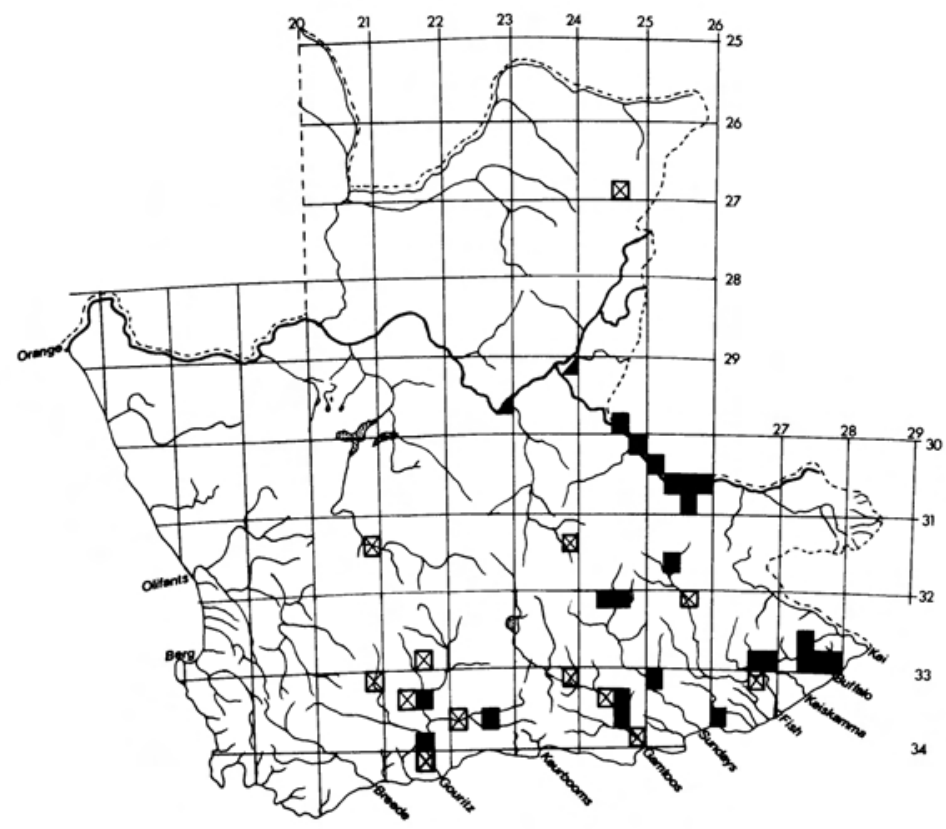

Fig. 9. Labeo umbratus

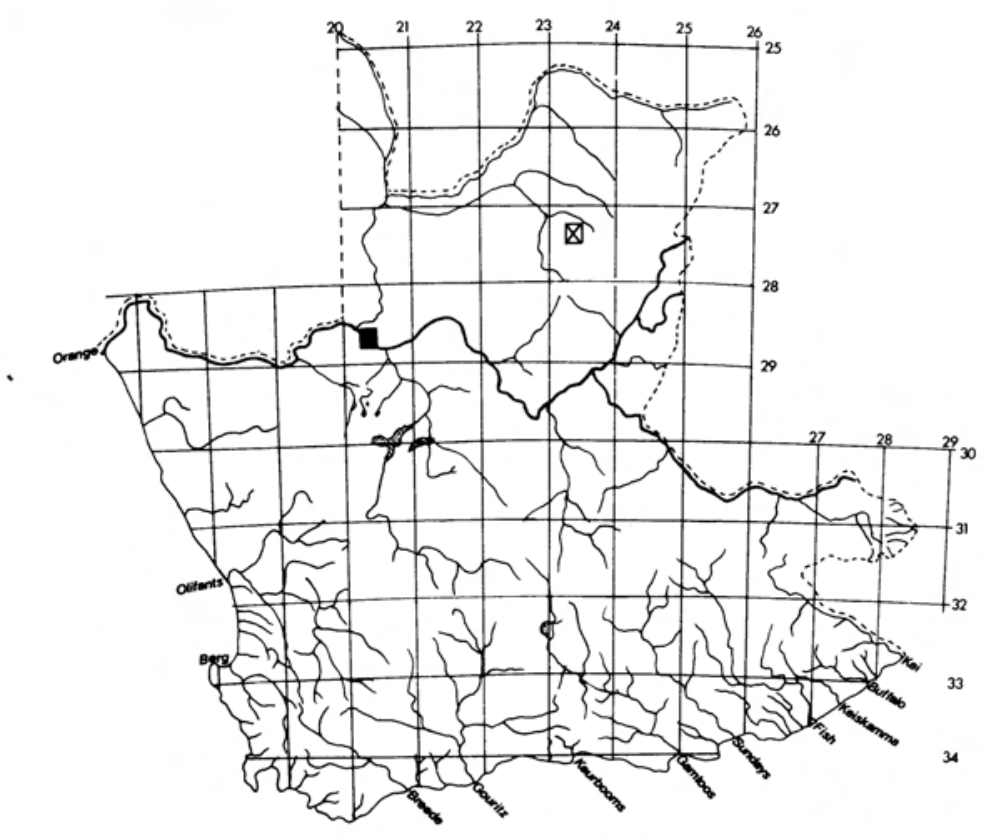

Fig. 10. Barbus trimaculatus 


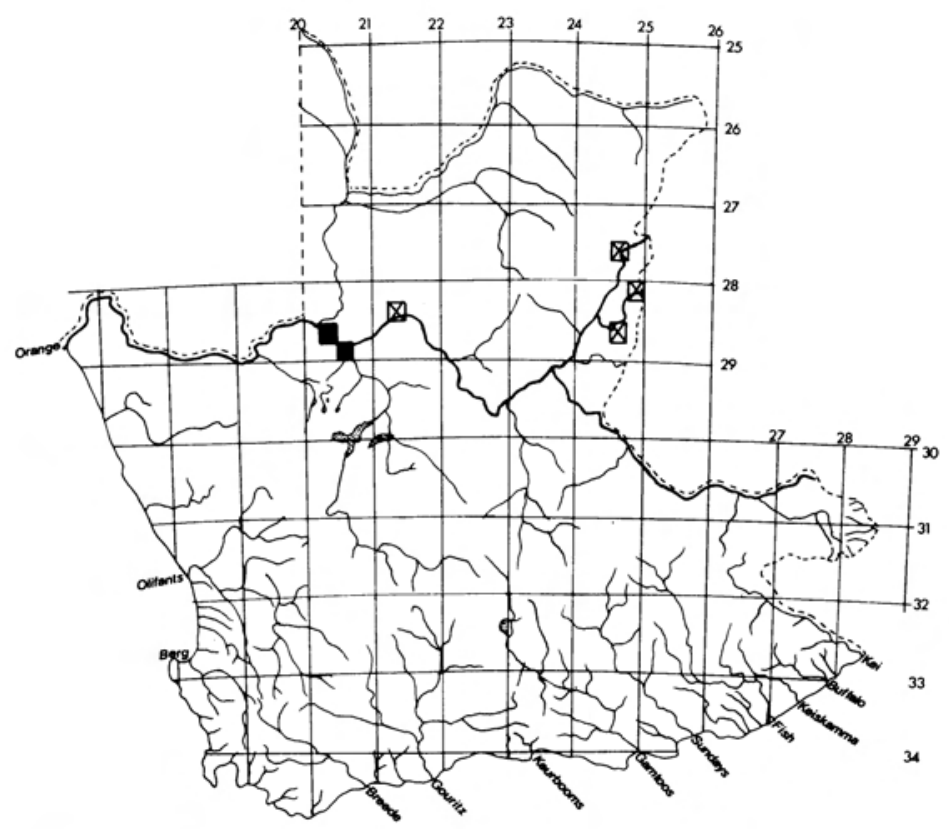

Fig. 11. Barbus paludinosus

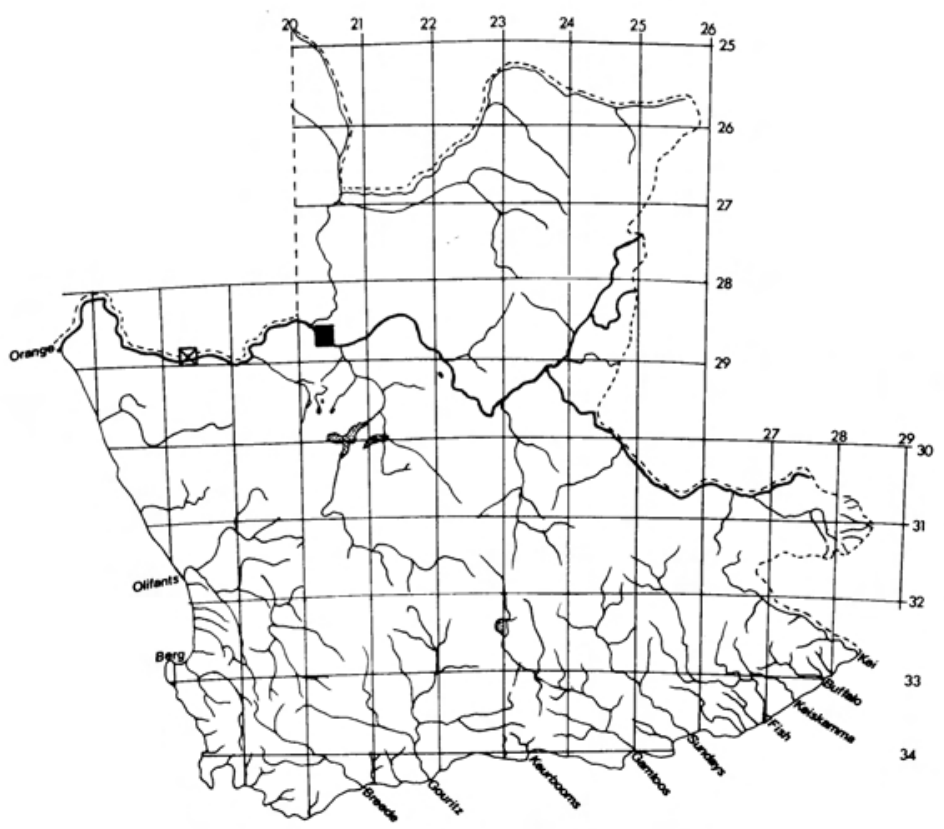

Fig. 12. Engraulicypris brevianalis 


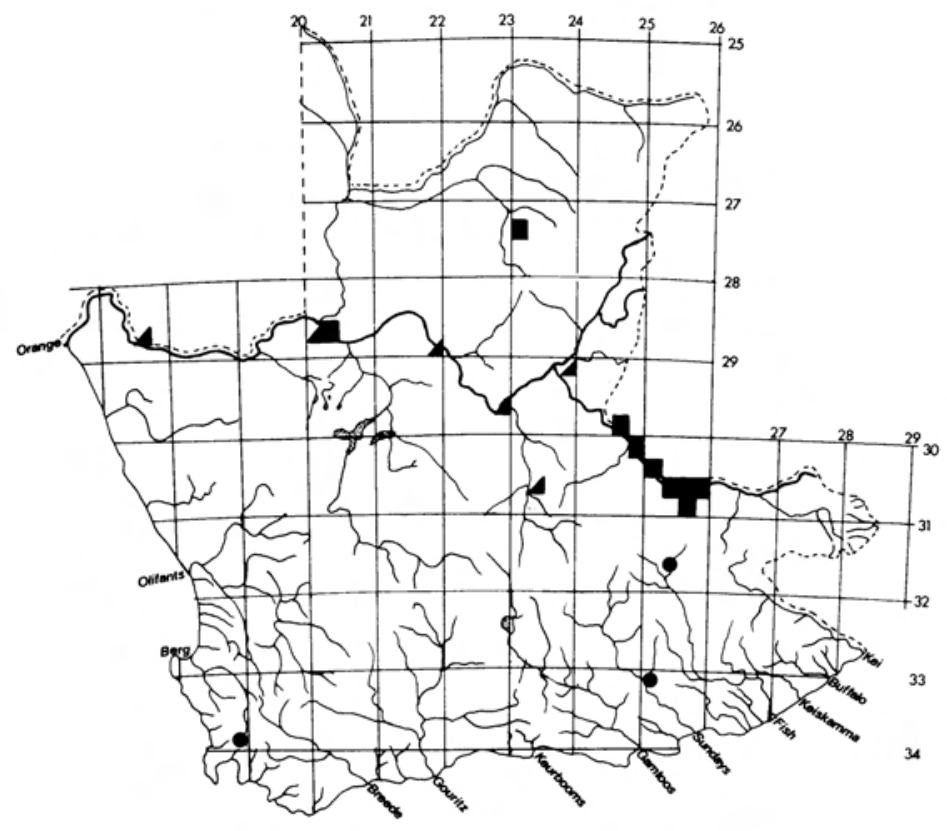

Fig. 13. Clarias gariepinus

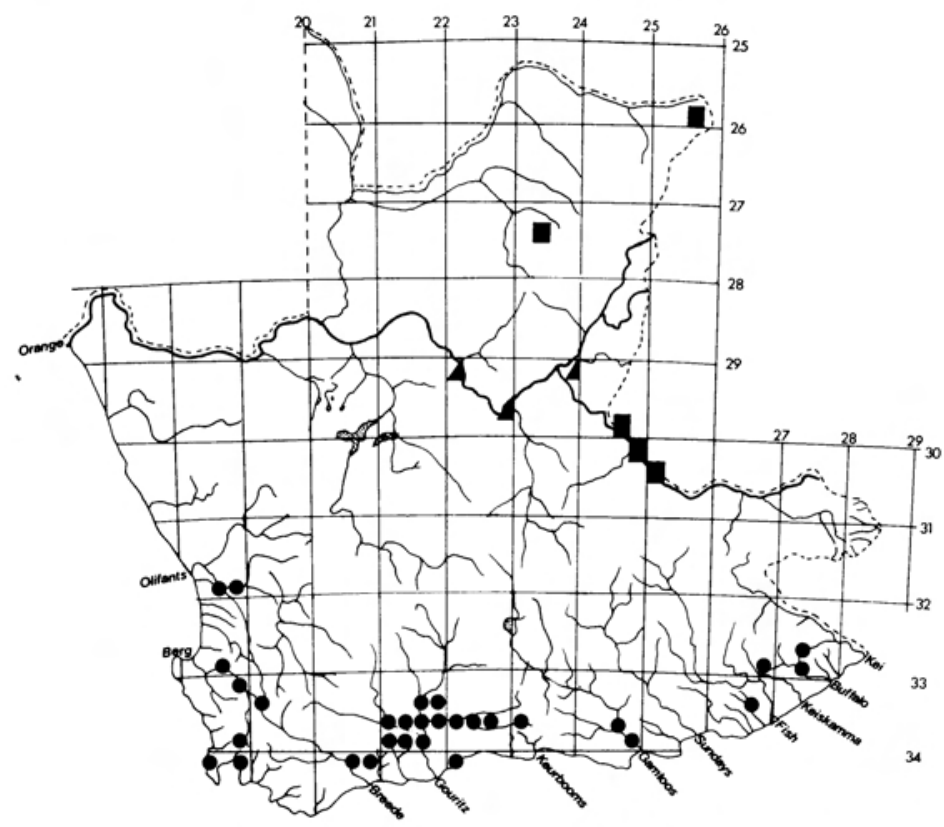

Fig. 14. Tilapia sparrmanii 


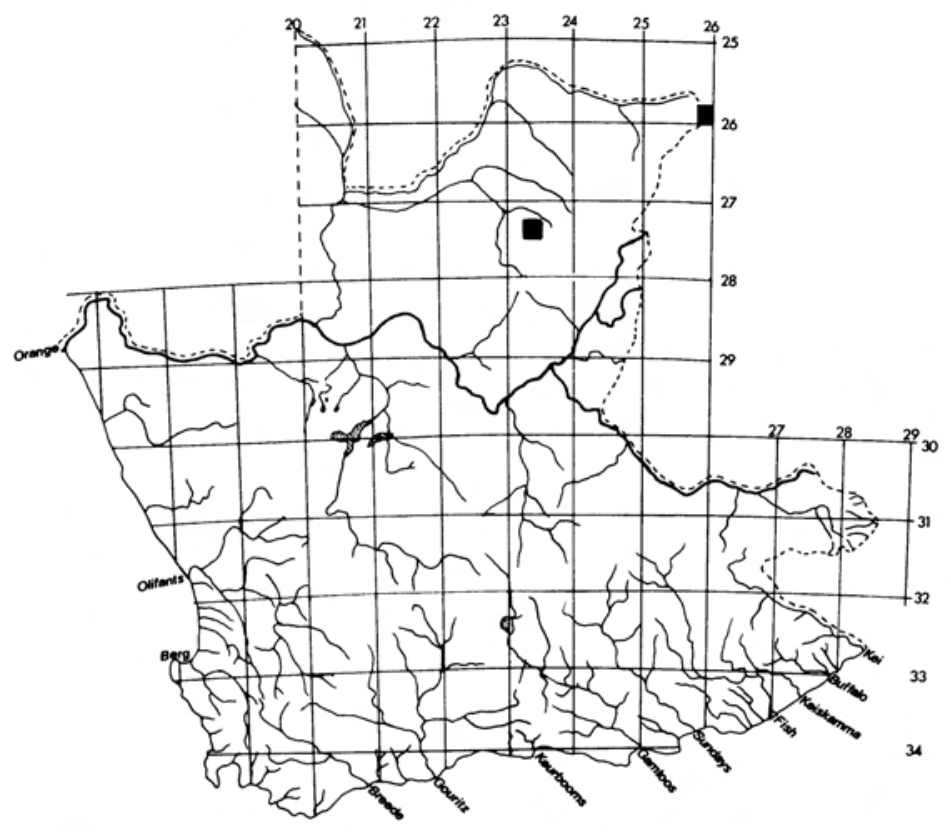

Fig. 15. Pseudocrenilabrus philander

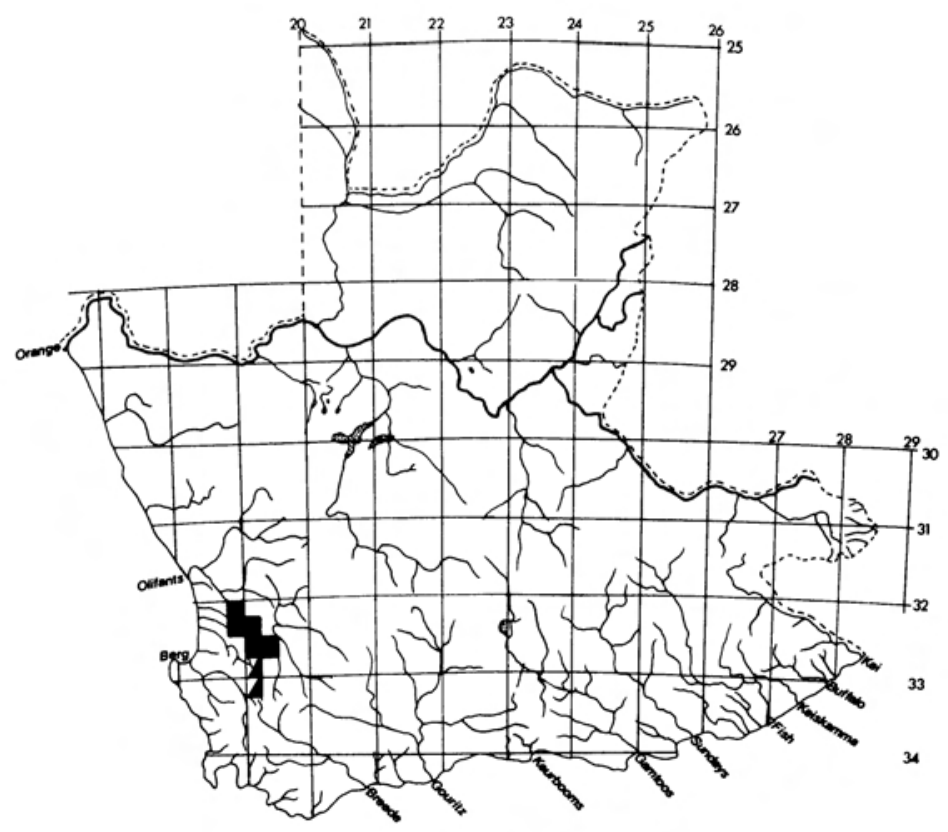

Fig. 16. Barbus capensis 


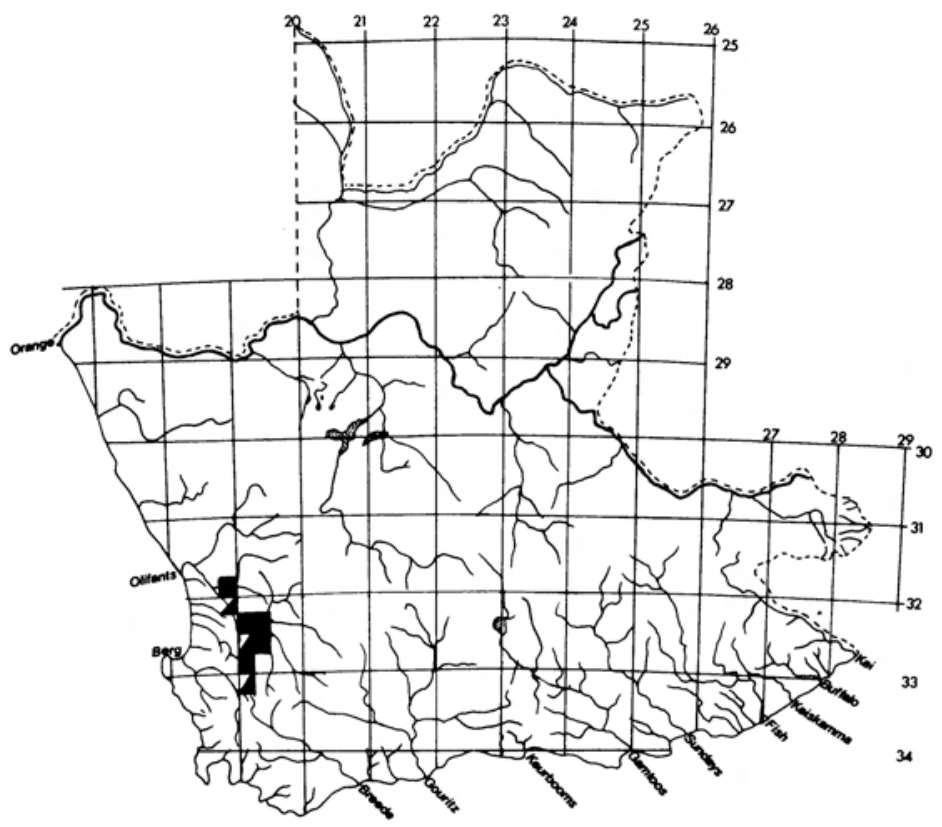

Fig. 17. Barbus serra

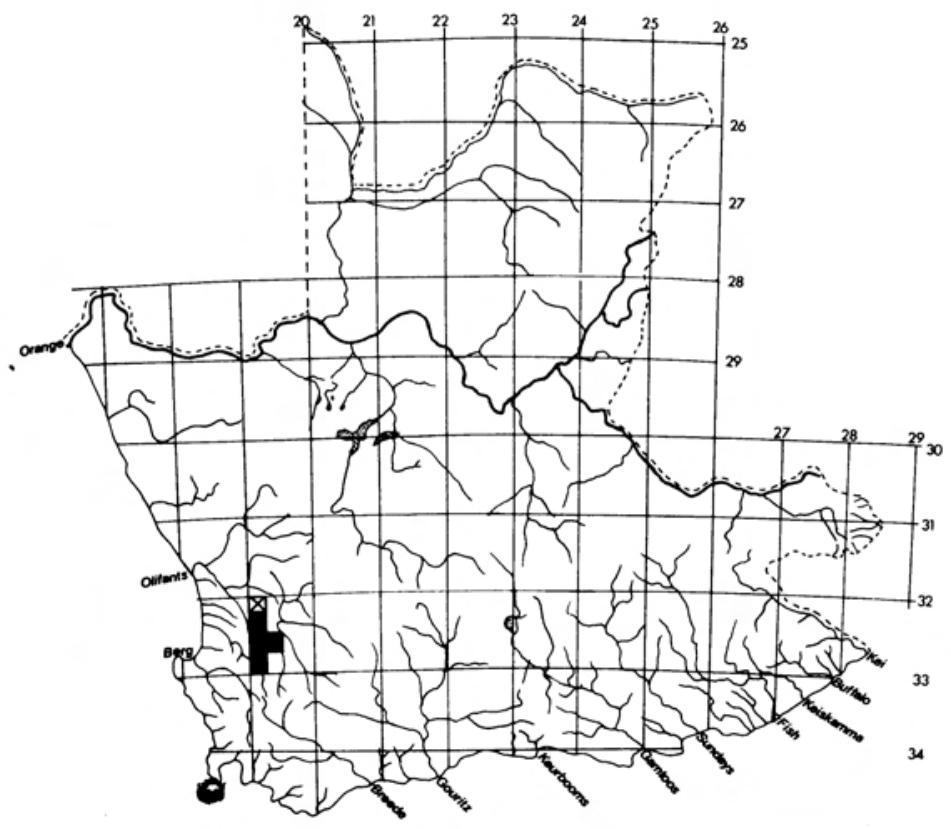

Fig. 18. Barbus calidus 


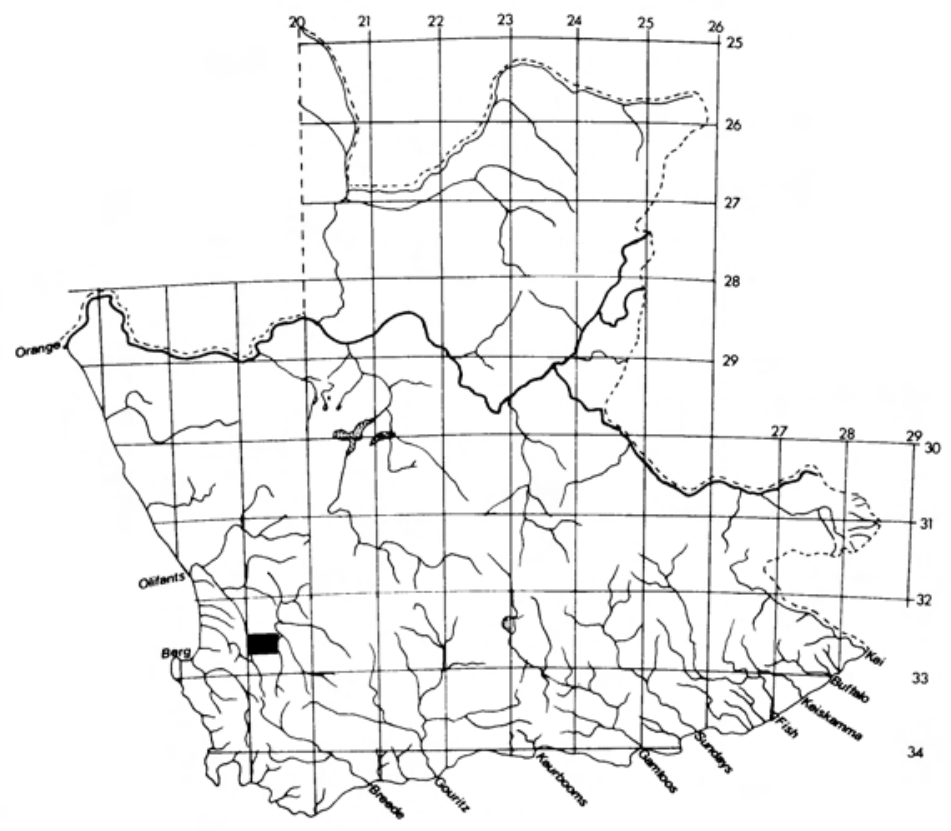

Fig. 19. Barbus erubescens

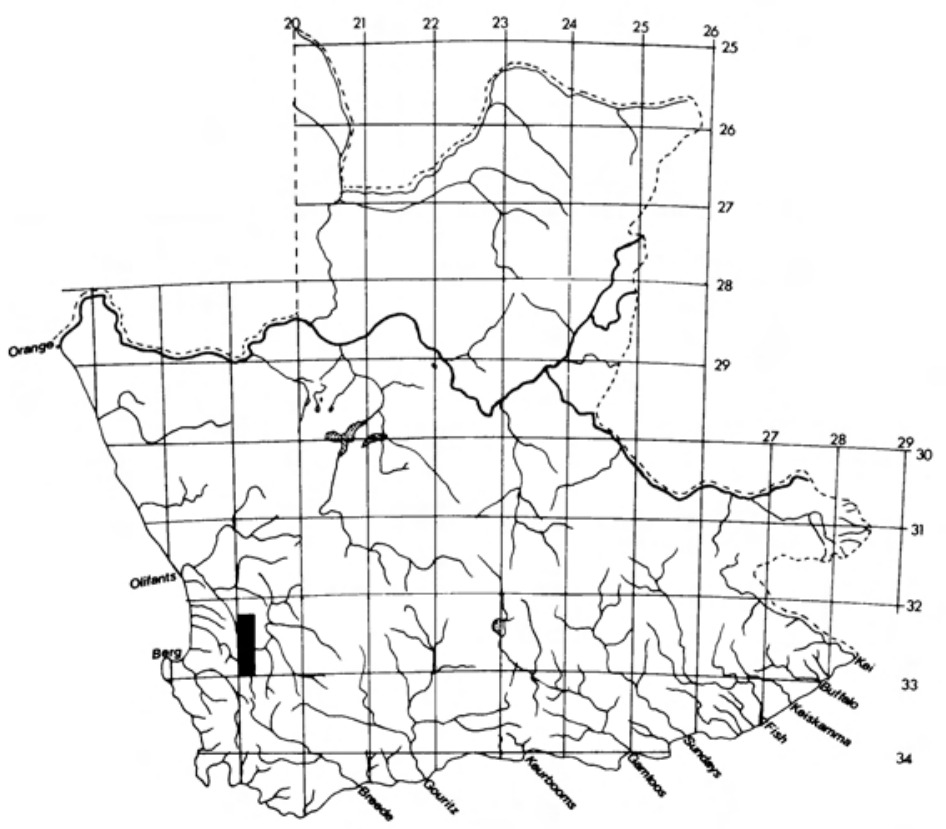

Fig. 20. Barbus phlegethon 


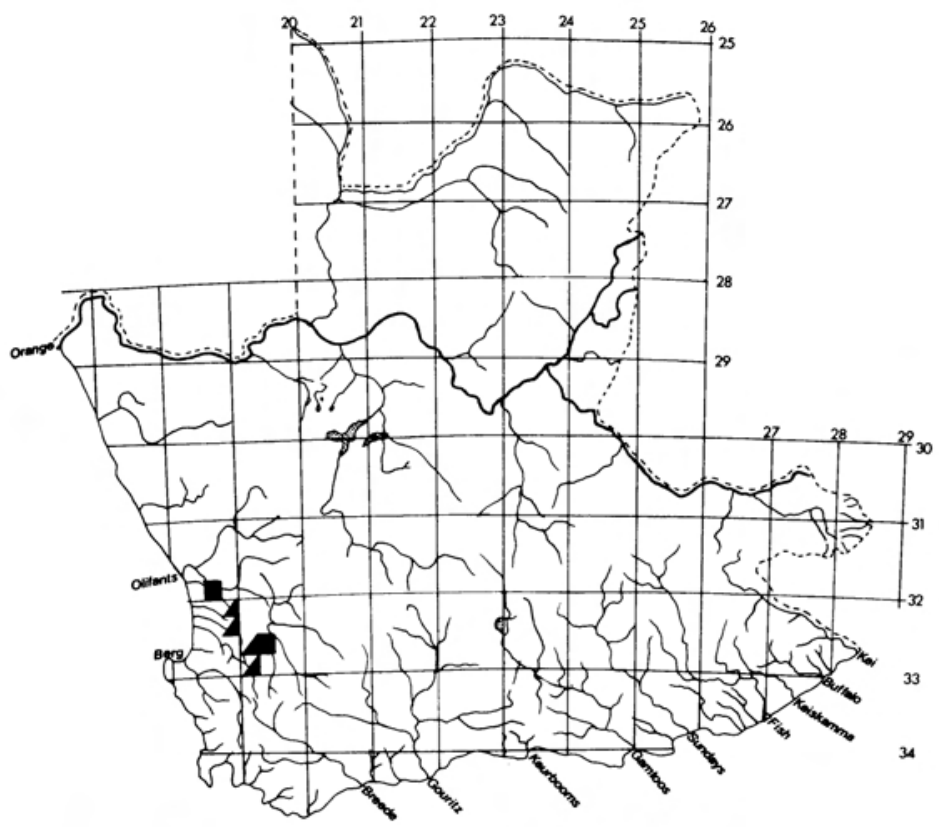

Fig. 21. Labeo seeberi

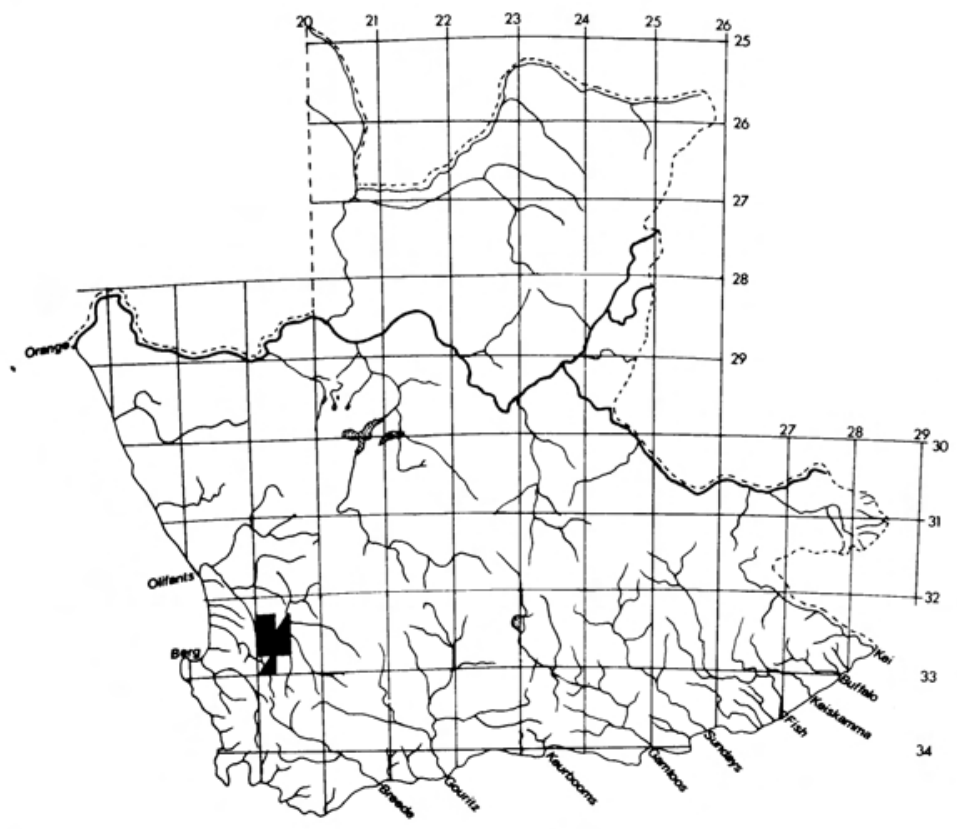

Fig. 22. Gephyroglanis gilli 


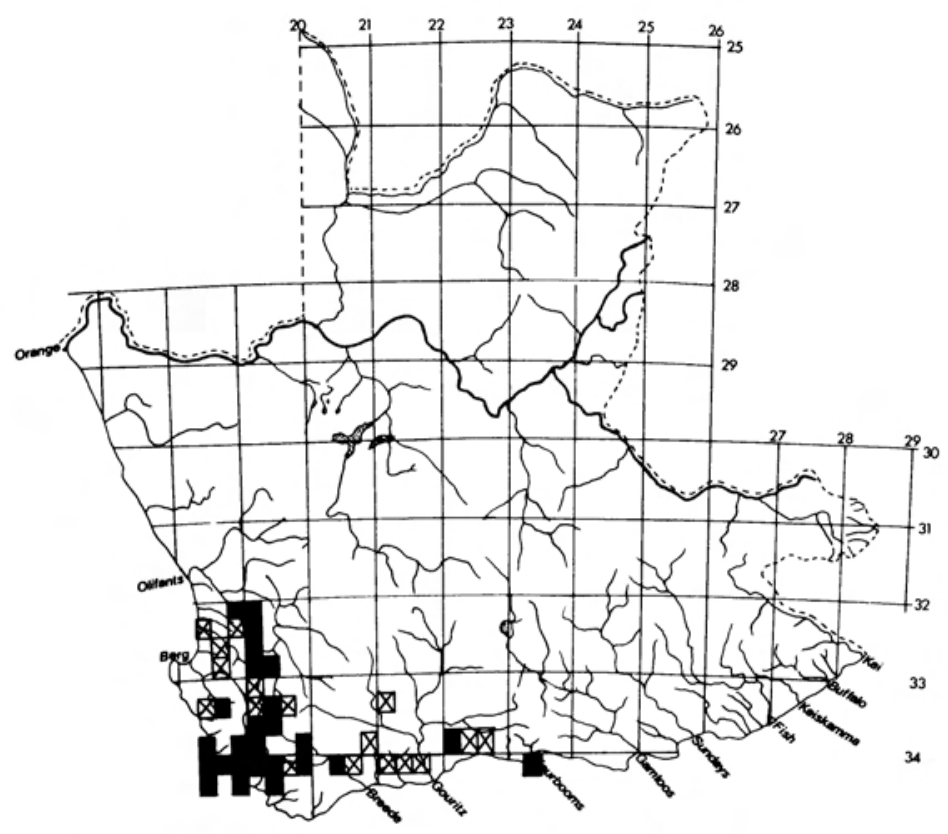

Fig. 23. Galaxias zebratus

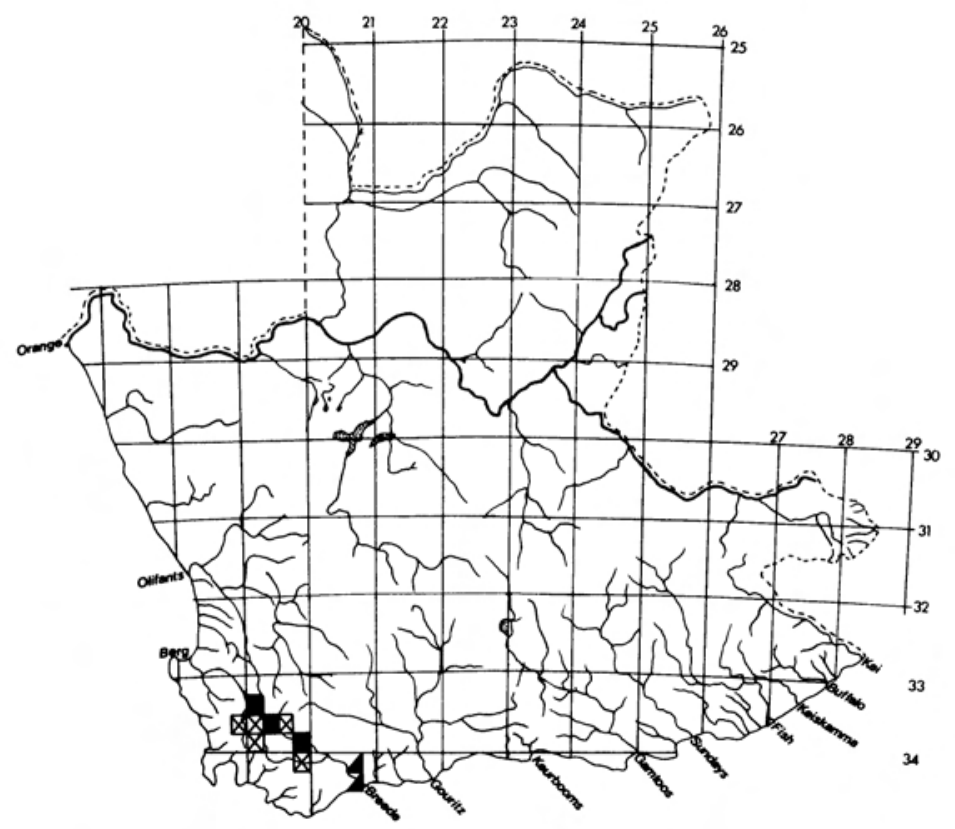

Fig. 24. Barbus andrewi 


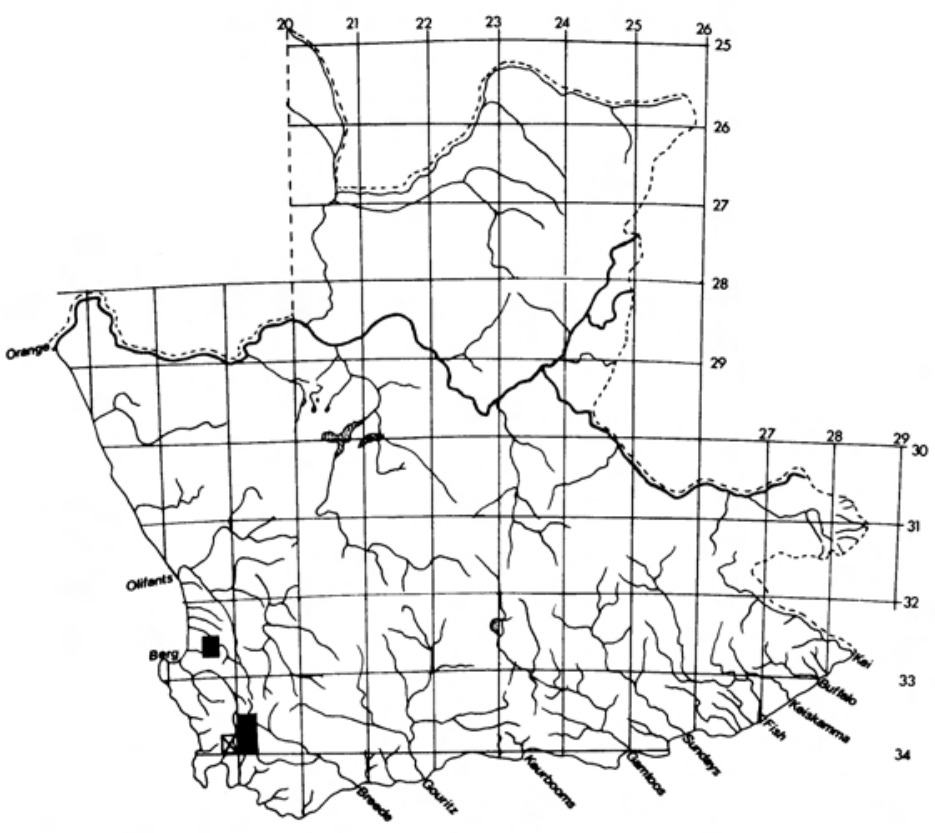

Fig. 25. Barbus burgi

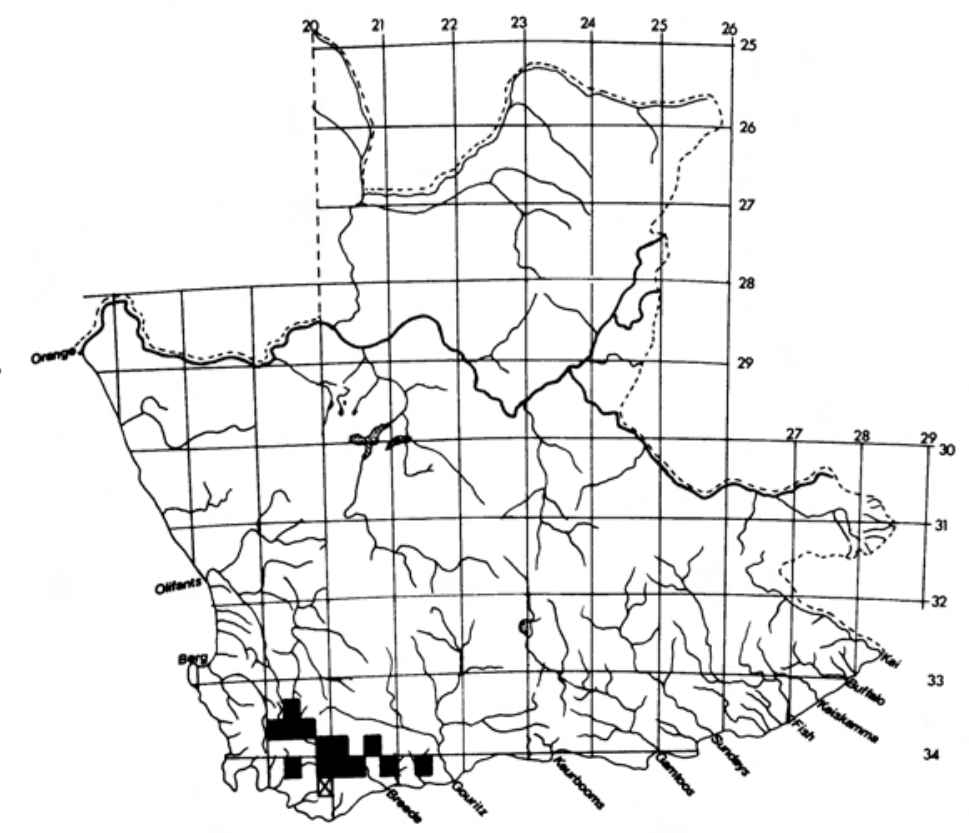

Fig. 26. Barbus burchelli 


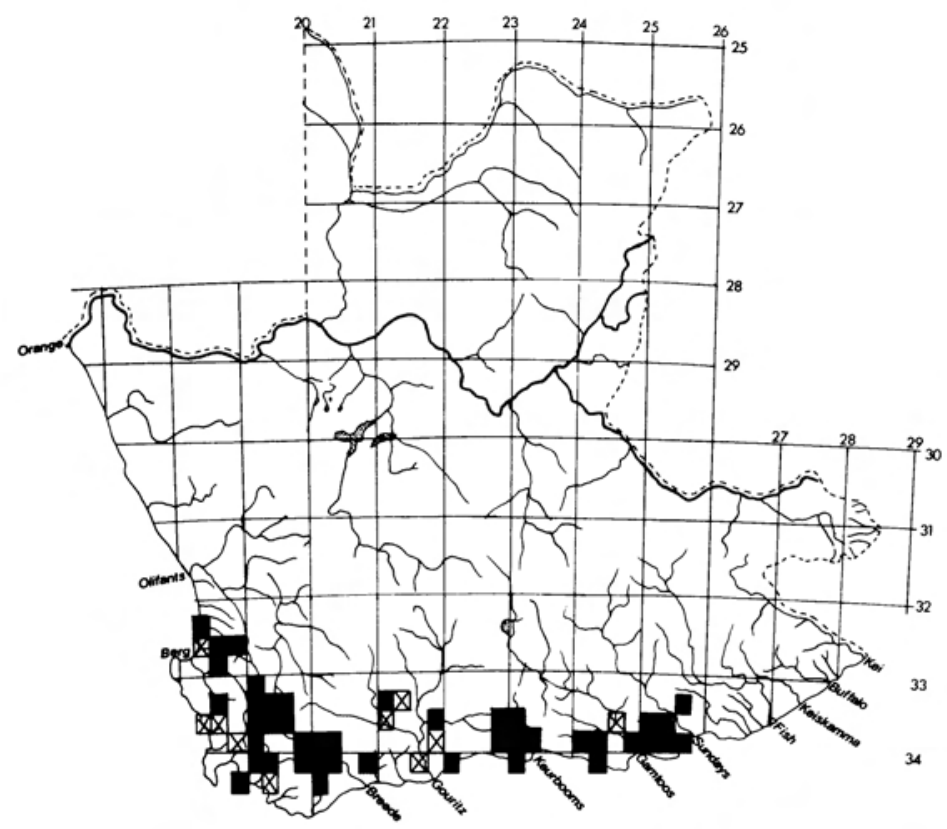

Fig. 27. Sandelia capensis

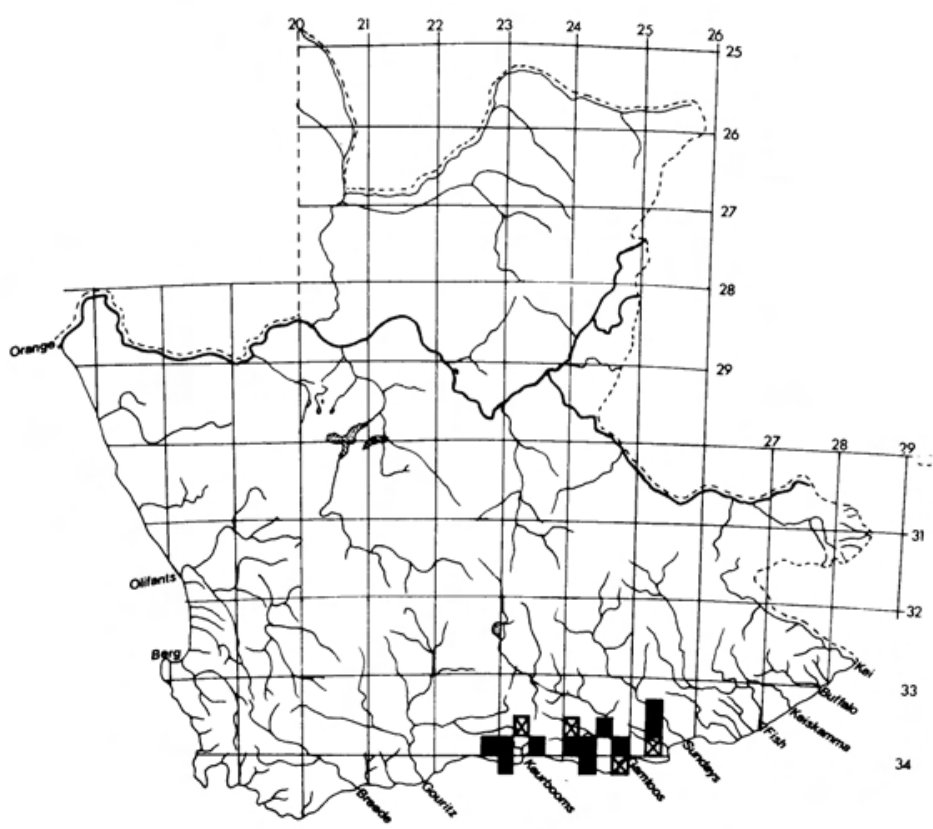

Fig. 28. Barbus afer 


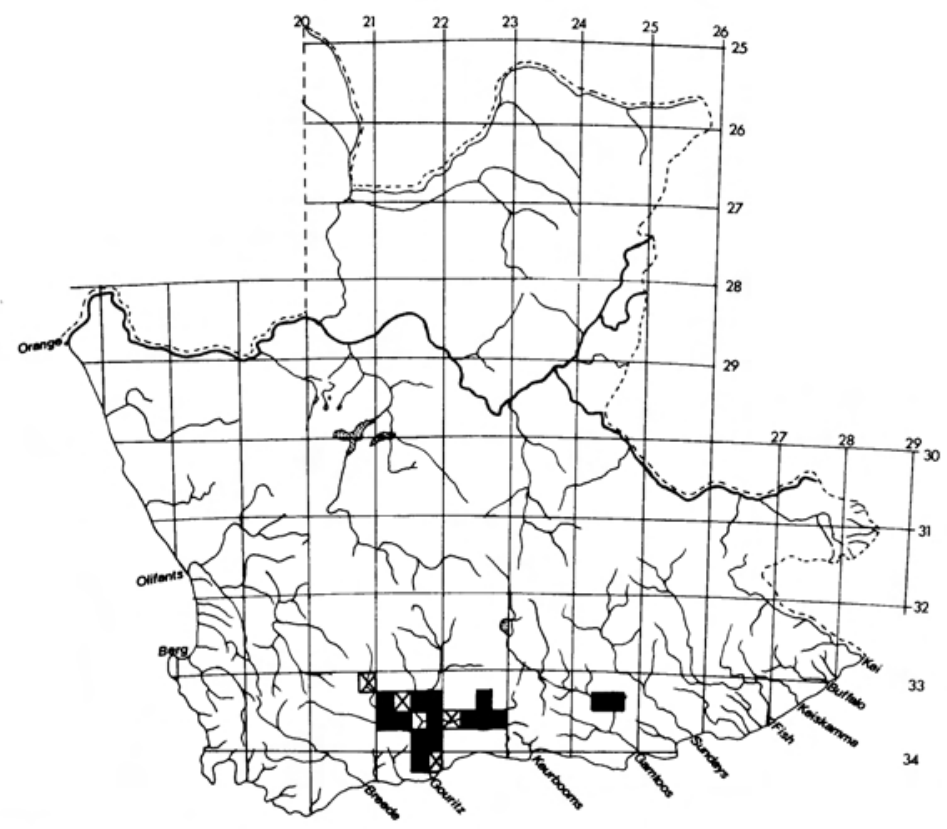

Fig. 29. Barbus asper

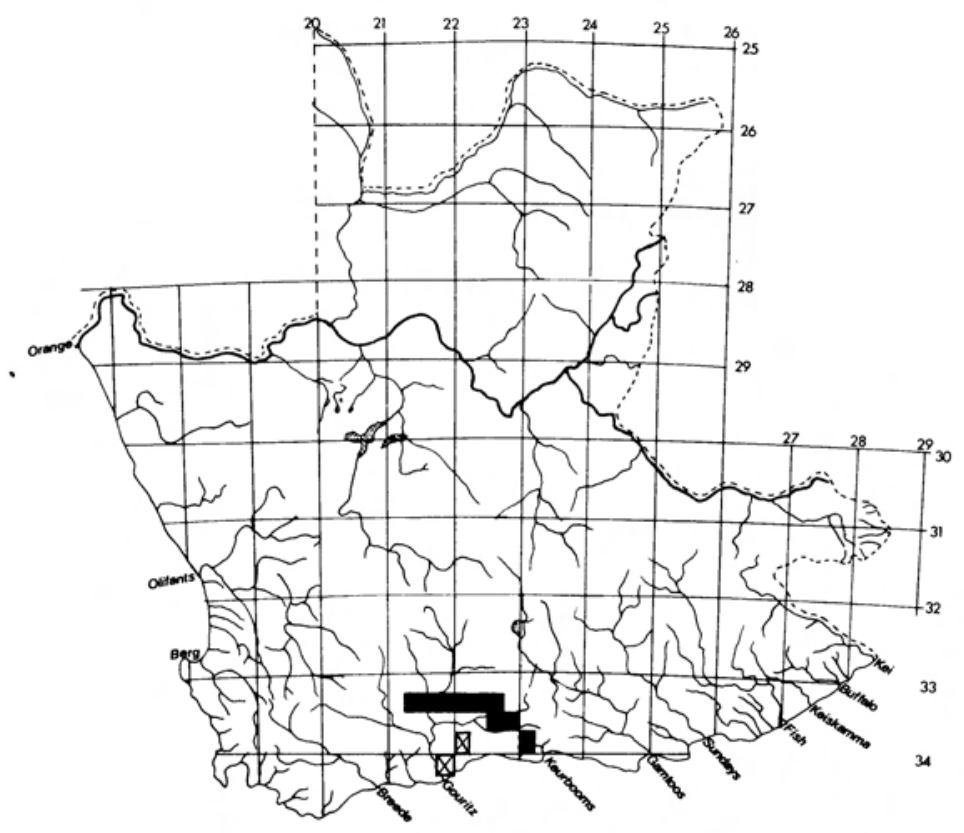

Fig. 30. Barbus tenuis 


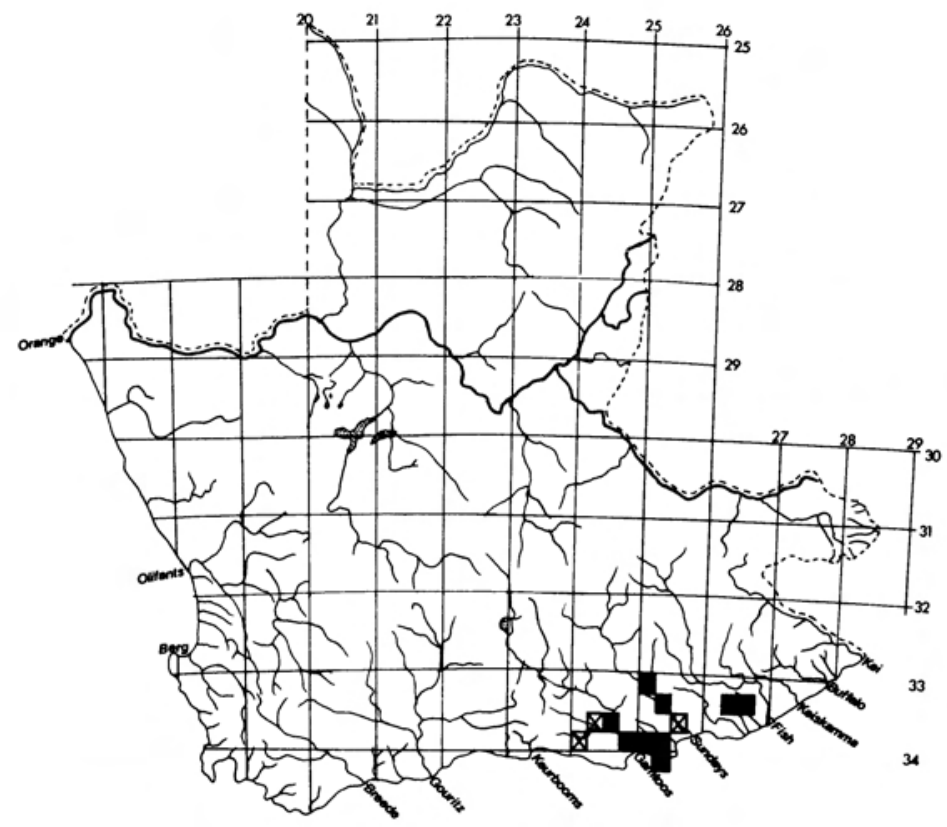

Fig. 31. Barbus pallidus

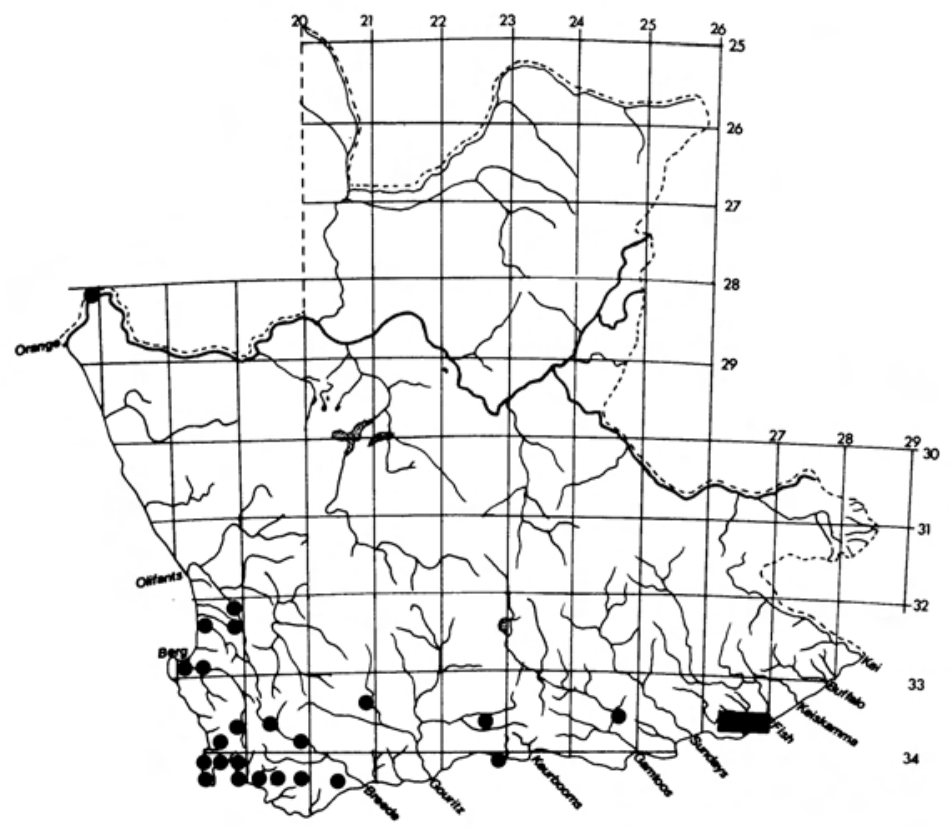

Fig. 32. Sarotherodon mossambicus 


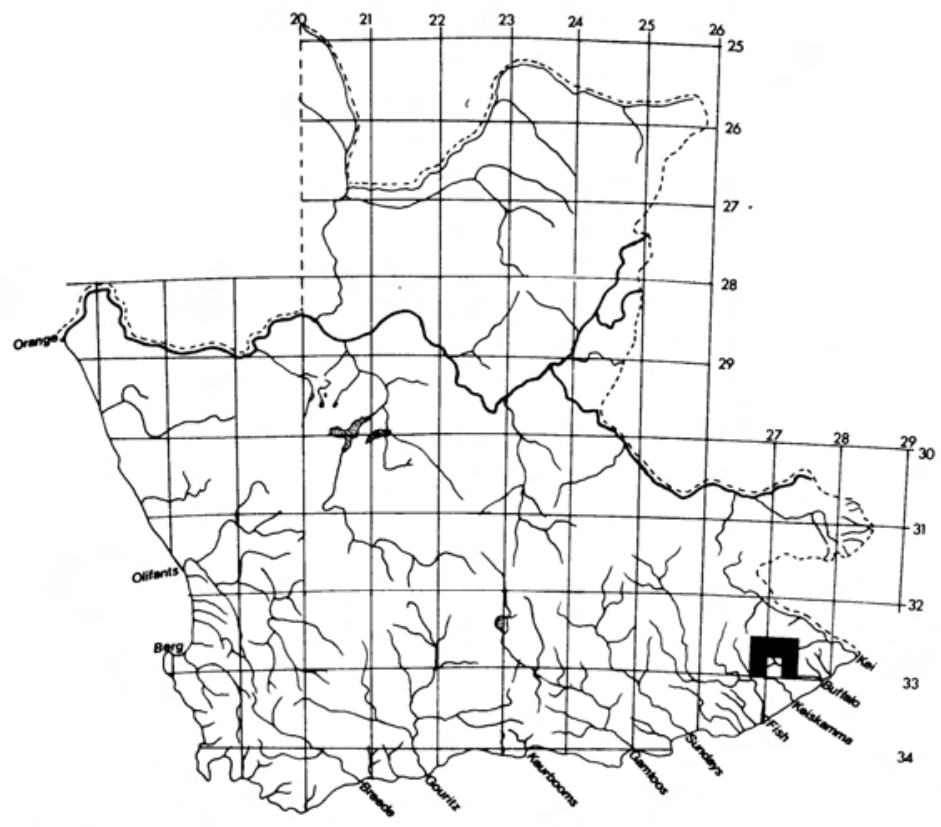

Fig. 33. Barbus trevelyani

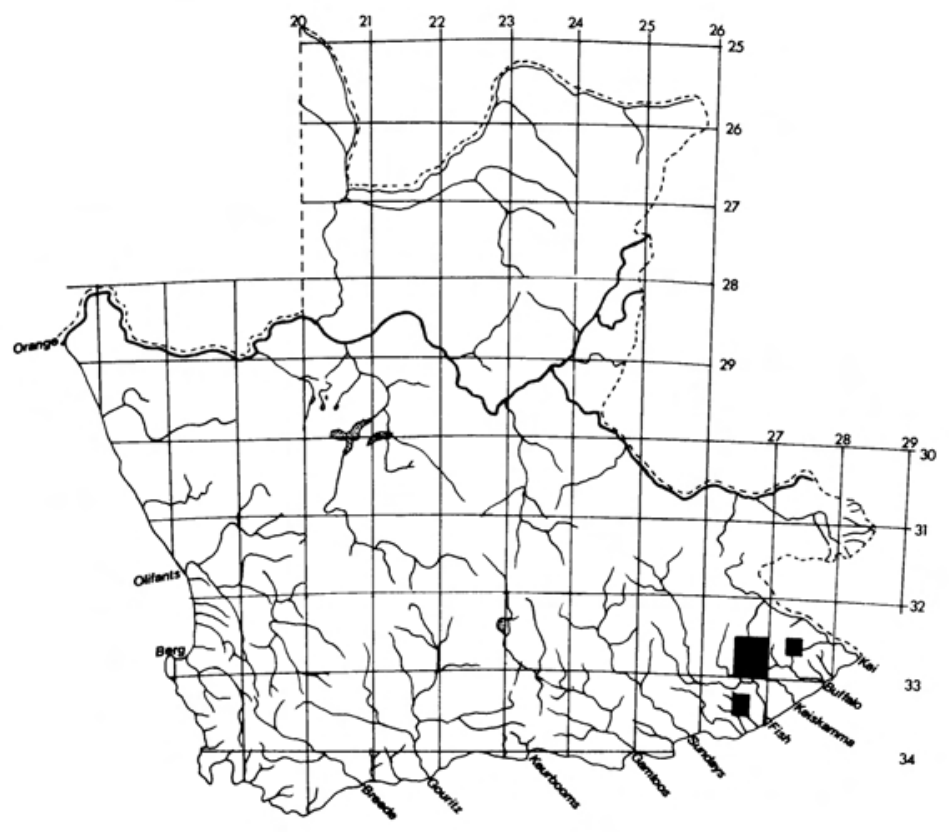

Fig. 34. Sandelia bainsii 


\subsection{Orange River System}

This is the only river system of those under consideration which is not confined to the boundaries of the Cape Province. The Augrabies Falls (grid reference $2820 \mathrm{CB}$ ) forms a geographical barrier to certain species separating the Lower Orange from the rest of the system. The Cape parts of this system have been sampled at only a few isolated sites.

\begin{tabular}{lll}
\hline \multicolumn{1}{c}{ Endemic } & Endemic to S.A. & Widespread \\
\hline Barbus holubi & B. anoplus & B. trimaculatus \\
B. kimberleyensis & B. pallidus* & B. paludinosus \\
B. hospes & L. umbratus & Engraulicypris brevianalis \\
Labeo capensis & & Clarias gariepinus \\
Gephyroglanis & & Tilapia sparrmanii \\
sclateri & & Pseudocrenilabris \\
& & philander \\
\hline
\end{tabular}

*Absent from Cape parts of Orange River System.

Barbus holubi is widespread and one of the most abundant species in the main Orange and its large dams. B. kimberleyensis is less abundant, partly because it occupies a higher trophic level but possibly also because of habitat deterioration. However, at present there is no reason for concern over this species in the Cape Province. B. hospes, which is confined to the Lower Orange, is the only species from this system listed in the South African Red Data Book (Skelton 1977). According to this author it is systematically clearly a unique species in the South African freshwater fish fauna.

Labeo capensis is widespread and abundant and is also favoured by the Orange River dams where numbers increase rapidly.

Gephyroglanis sclateri occurs only above the Falls where it seems to be widespread in perennial streams and abundant at certain sites. It prefers a rocky substratum and is possibly dependent on running water or cannot survive in silted areas because it has disappeared from the H.F. Verwoerd Dam. Anglers reports indicate that the numbers of this species might be declining generally and a study of its ecology has become necessary.

Barbus anoplus is apparently also absent from below the Falls. In contrast to other Orange River System minnows this species is abundant and widespread in the Cape parts of the system. It is also favoured by conditions created by the large Orange River dams. The Orange River form of $B$. anoplus differs morphologically from other populations in the Cape (Barnard 1943; Gaigher 1976).

Labeo umbratus is widespread but seems to be less abundant in both the river and dams than in the Vaal River where high densities have been recorded by Groenewald (1957) and Mulder (1973).

Although Barbus trimaculatus and B. paludinosus are unspecialised and 
widely distributed further north (Jubb 1967; Gaigher 1974), both have been collected only at a few sites in the Orange River and only as far upstream as immediately above the Augrabies Falls. B. paludinosus was previously collected at Upington and at a few sites along the Vaal River (Barnard 1943). No recent surveys have been done in these areas, however. Intensive collections in the vicinity of the H.F. Verwoerd Dam and P.K. le Roux Dam over the past seven years showed that they are absent from this area.

Engraulicypris brevianalis is confined to the Lower Orange and was abundant at all three sites where it was collected namely at Ais-Ais (pers. obs. I.G.G.), Goodhouse (Barnard 1943) and immediately below the Falls (C.M. Gaigher pers. comm.).

Although surprisingly few specimen records exist, surveys and angler's reports show that Clarias gariepinus is widespread and abundant. It also favours a dam habitat. This species populated the Fish River System via the Orange-Fish Tunnel (Cambray \& Jubb 1977) and escaped into the Eerste River from the Jonkershoek fish hatchery.

The Albany Museum collection contains only one specimen record of Tilapia sparmanii from its natural range in the Orange River, namely a recent collection from the P.K. le Roux Dam. It has been recorded at a few sites lower down. It has also been collected from the fountain at Kuruman and Wondergat near Mafeking. This species has been introduced into several Cape rivers as food fish for bass. .

Within the Cape Pseudocrenilabris philander has only been recorded at Wondergat and the Kuruman Eye.

\subsection{Olifants River System}

This system is characterized by extremely clear, oligotrophic streams except in the lower reaches where the water is turbid due to agricultural runoff. The system has been surveyed fairly intensively by Van Rensburg (1966) and Gaigher (1973).

\begin{tabular}{ll}
\hline Endemic & Endemic to S.A. \\
\hline Barbus capensis & Barbus anoplus \\
B. serra & Galaxias zebratus \\
B. calidus & \\
B. erubescens & \\
B. phlegeton & \\
Labeo seeberi & \\
Gephyroglanis gilli & \\
\hline
\end{tabular}

Gaigher (1973) found that, within their restricted distribution ranges, Barbus capensis, B. serra, B. calidus, Labeo seeberi and Gephyroglanis gilli were still fairly abundant in 1970 although exotic predators had a drastic effect 
on their distribution. This was markedly so in the case of $B$. capensis which was thought to be rapidly declining. $B$. erubescens which was only discovered and described recently by Skelton (1974) is also confined to two small streams separated from the rest of the system by a waterfall. Galaxias zebratus is widespread and abundant.

\subsection{Great Berg, Breede and adjacent rivers}

The rivers in this area have been particularly subject to negative human influences and recent surveys showed that certain sections of main streams are completely devoid of indigenous freshwater fishes.

\begin{tabular}{ll}
\hline Endemic & Endemic to S.A. \\
\hline Barbus andrewi & Galaxias zebratus \\
B. burgi & Sandelia capensis \\
B. burchelli & \\
\hline
\end{tabular}

Barbus andrewi is the only endemic to this region which is not listed in the South African Red Data Book. However, there is reason for concern about its survival. According to Barnard (1943) this species previously occurred throughout the Berg and Breede River Systems but recent surveys have shown that it now has a restricted distribution. Fortunately it is favoured by inundation and is abundant in the Brandvlei Dam.

B. burgi is restricted to the Verlorenvlei and upper Berg Rivers. It seems to be extinct in the Eerste River where it was recorded by Barnard ( $o p$. cit). At least one stream that flows into the Wemmershoek Dam still contains B. burgi despite heavy stocking of the dam with trout over a long period. A more detailed study of this situation is required. The status of this species should be elevated to "endangered".

$B$. burchelli has a relatively wide distribution and recent surveys showed that healthy populations still occur in several tributaries.

Sandelia capensis and Galaxias zebratus are abundant and widespread in this region.

\subsection{Gouritz to Kariega Rivers}

\begin{tabular}{llc}
\hline Endemic & Endemic to S.A. & Widespread \\
\hline Barbus afer & B. anoplus & Sarotherodon \\
B. asper & B. pallidus & mossambicus \\
B. tenuis & Labeo umbratus & \\
& Sandelia capensis & \\
& Galaxias zebratus & \\
\hline
\end{tabular}


The taxonomic status of Barbus afer and B. asper is at present under revision by $\mathrm{P}$. Skelton of the Albany Museum. Skelton kindly supplied the information for the distribution maps which show that $B$. asper occurs in the Gouritz and parts of the Gamtoos River Systems while B. afer is found in coastal rivers east of the Gouritz and in the Keurbooms, Gamtoos and Sundays Rivers. Both are listed as rare in the South African Red Data Book. $B$. asper has been collected from the Calitzdorp and Stompdrift Dams and therefore appears to benefit by inundation. This matter requires investigation.

B. tenuis is confined to the Gouritz and Keurbooms River Systems. According to Skelton (1977) it prefers small, clear flowing streams with shallow pools.

B. anoplus is widespread in the Gouritz and Sundays Rivers. During the present survey it was collected from the upper reaches of the Gamtoos River System for the first time.

B. pallidus occurs south of $33^{\circ}$ from the Gamtoos to Kariega Rivers. Although this species is abundant in Transvaal tributaries of the Vaal River, this isolated population should be conserved in order to maintain the genetic diversity of the species.

Labeo umbratus is abundant throughout the region apart from being absent from certain coastal rivers.

Sandelia capensis is abundant in this region too. It occurs as far east as the Swartkops River at Port Elizabeth.

Galaxias zebratus is abundant but occurs only as far east as the Keurbooms River.

The natural distribution of Sarotherodon mossambicus extends as far south as the Bushmans and adjacent Rivers. It has been introduced into virtually all the larger Cape river systems, often to the detriment of angling and probably also the other species.

\subsection{Kowie to Nahoon Rivers}

\begin{tabular}{llc}
\hline Endemic & Endemic to S.A. & Widespread \\
\hline Barbus trevelyani & B. anoplus & Sarotherodon \\
Sandelia bainsii & Labeo umbratus & mossambicus \\
\hline
\end{tabular}

Barbus trevelyani is the only Cape minnow of which the ecology has been studied in any detail. Gaigher $(1975,1979)$ showed that, although it is still abundant in certain streams within its limited distribution, these populations are far from healthy. If present trends continue it has a slim chance of surviving in its natural range.

Sandelia bainsii also has a restricted distribution but is abundant and does not seem to be seriously affected by human induced changes to rivers. 
Barbus anoplus and Labeo umbratus are widespread and abundant. According to Jubb (1967 and in litt.) L. umbratus may have been introduced to the Keiskamma, Buffalo and Nahoon rivers by anglers. However, no definite proof of this could be found so it is recorded as natural distribution.

Sarotherodon mossambicus is restricted to warmer waters near the coast.

Barbus holubi, Labeo capensis and Clarias gariepinus have colonised this region from the Orange River System through the Orange-Fish Tunnel (Cambray \& Jubb 1977).

\section{Factors affecting survival}

As a result of the Cape Province's long history of European settlement the habitat of its freshwater fishes have been subjected to more changes than other areas in South Africa. Combined to this the climate is highly erratic over most parts and many rivers are acid and oligotrophic with a natural scarcity of species and numbers. From a conservation viewpoint Cape freshwater fishes have adapted to certain natural environmental conditions (abiotic and biotic) through long periods of natural selection. Any human induced change can therefore be expected to influence their gene pools which would then be undesirable, independent of whether numbers decrease or increase. Angling and commercial fisheries, on the other hand, could benefit by certain of these changes. Conservation departments must try to satisfy both these interests and it is therefore essential to identify and consider the various factors listed below.

\subsection{Farming and related forms of land use}

Various farming activities over the past 300 years have probably been the major factors in the decline of Cape fishes. Activities like overgrazing, tree felling, ploughing, substitution of natural flora with exotics and water extraction can have the following negative effects on aquatic habitats:

\subsubsection{Siltation or sand deposition and increased turbidity}

According to Edwards (1969) South Africa has amongst the highest rates of soil erosion in the world due to land use practices. This author is of the opinion that macrophytes are negatively affected by siltation and increase in turbidity. The paucity of floating macrophytes and an unstable substrate is also the result of flood rip caused by large fluctuations in river levels due to rapid runoff from a denuded landscape. As demonstrated by Chutter (1969) siltation will also affect the majority of stream invertebrates. The effect on substrate, macrophytes and stream invertebrates will naturally be reflected in the fish populations. Apart from affecting their 
food source sand and silt deposition also reduce cover and change water temperature. It can also cover breeding sites. According to Skelton (1977) this factor is probably causing the decline of five threatened Cape fish species.

\subsubsection{Water extraction}

Due to the irregular rainfall patterns with long periods of drought Cape fishes are extremely vulnerable to water extraction. In the winter rainfall region where most of the threatened species occur the dry hot summer period coincides with the period of greatest water need for agricultural purposes. Water extraction can also increase the effects of pollution by concentrating pollutants. According to Skelton (op cit.) water extraction is probably causing the decline of six threatened Cape species.

\subsubsection{Mineralisation and eutrophication}

Increasing mineralisation due to irrigation runoff is a serious negative factor in at least two large rivers namely the Berg and Breede. Recent surveys have shown that the lower reaches of these rivers contain few indigenous fishes. This is probably the result of a combination of factors but mineralisation no doubt plays a role.

Eutrophication increases the productivity of rivers favouring certain species above others. Hardy exotics such as blue gill sunfish and carp may increase under such conditions to the detriment of indigenous species which are adapted to an oligotrophic environment.

\subsubsection{Pesticides and herbicides}

Pesticides and herbicides usually have a localised influence but could be significant in the case of extremely rare species.

\subsubsection{Removal or change of riverine vegetation}

In most Cape rivers, which are characteristically oligotrophic, fishes probably exist largely on a detritus food chain. Removal of vegetation can seriously disrupt these food chains while a change in vegetation can change the colour and organic load of the water with resultant changes in food organisms. The effects of such changes have not been studied in the Cape Province but should be kept in mind when evaluating the status of fishes. 


\subsection{Exotics}

Here any species not occurring naturally in a system is considered to be an exotic whether it is foreign to South Africa or not. Exotics can threaten fish species through predation, competition and genetic swamping (hybridisation). Exotics introduced for angling, commercial utilisation, forage fish, bait, pets or for insect or aquatic weed control is considered to be one of the major reasons for the decline of threatened species throughout the world (Alfred 1968; Mc. T. Cowan 1973; Maitland 1974; Moyle 1976; Tilzey 1976). Skelton (1977) lists predation as a factor threatening nine of the 12 Cape Red Data species. The smallmouth bass Micropterus dolomieu, which has been introduced into virtually every river system in the Cape Province, has been the most destructive predator. The effect of predation is increased by water extraction and siltation which forces species out of their preferred habitats into areas where they are more vulnerable.

The negative effects of competition by non-predaceous exotics for food, space or breeding sites is another problem which has often been neglected in fisheries management in this country. Species such as Mozambique tilapia Sarotherodon mossambicus and banded tilapia Tilapia sparrmanii have and are being widely distributed to waters where they can possibly survive or be of benefit as fodder fish without realising their effect on indigenous species.

As far as we know hybridisation between closely related species has fortunately not yet occurred in the Cape Province but this factor should be seriously considered. Indiscriminate distribution of indigenous angling fishes could even be more disastrous to angling and conservation than the effect of foreign species. For example, being the most popular indigenous angling fishes in South Africa the various yellowfish species are being propagated for distribution by several state hatcheries. As fate would have it the yellowfishes are candidates for interbreeding and the hybrid of at least two species has proved to be fertile (Mulder pers. comm.). The closely related species, or possibly subspecies, are Barbus holubi and B. kimberleyensis in the Orange, $B$. cf. kimberleyensis in the Upper Fish river, S.W.A., $B$. polylepis of the Limpopo and Incomate River Systems, B. natalensis of the Tugela and $B$. capensis of the Olifants, western Cape. Interbasin transfer poses a real and serious threat to our indigenous species but fortunately we are in a position to learn from the mistakes of others. For example, Moyle (op. cit.) points out that three Californian fish species have become endangered due to interbasin transfers.

\subsection{Mining, industrial development and human settlement}

The use of water for human needs, industries and discharge of domestic and other wastes and physical changes to the environment leads to chemical pollution, eutrophication, heating, watershed connection, chemical changes to water, increased runoff from roads, direct physical destruction 
of streams, channelisation, etc. Through direct or indirect effects on fish, eutrophication is probably the most important of these factors in the Cape Province. Fortunately the effects are limited to a certain degree because the three largest cities are situated near the coast.

3.4 The construction of dams and weirs for irrigation, domestic or industrial use, hydro-elecricity or flow regulation

Although the building of dams and weirs are essential in a droughtprone province it is nevertheless necessary to identify their possible negative effects on the survival of threatened species for consideration in management planning.

\subsubsection{Barriers to migration}

Little is known of the migration of Cape freshwater fishes but incidental observations and anglers reports indicate that at least most of the larger species undertake breeding migrations or disperse during flood periods. Man made physical barriers must therefore have a negative influence but it is doubted whether this factor alone threatens the survival of any freshwater species.

\subsubsection{Drown spawning or feeding grounds or serve as silt traps}

Little information is available on this aspect. Most Orange River species benefit by dams because more favourable spawning and feeding grounds are created. Even in the case of yellowfish, which are known to spawn in running water, wave action along gravel shores can simulate natural spawning conditions. However, at least one Orange River species namely Gephyroglanis sclateri cannot exist in some dams. Gaigher (1975) found that the endangered Barbus trevelyani cannot exist in dams or above weirs.

\subsubsection{Create new states of thermal stratification with effects on temperature and oxygen downstream}

These effects are limited but could be significant if several weirs are constructed in small streams that harbour threatened species.

\subsubsection{Influence breeding cycles}

The breeding cycles of freshwater fishes are obviously adapted to natu- 
ral temperature and flow regimes. If water level fluctuations in dams and release of water from them do not simulate natural conditions, especially if the water temperature is affected as well, breeding cycles could be disrupted with negative influences on fish populations.

\subsubsection{Establish habitat for undersirable species}

Dams create unnatural habitats which could be suitable for undesirable fish species such as carp and bluegill sunfish. Anglers are inclined to exert pressure on conservation departments to stock new dams with foreign or exotic species in the false belief that this will miraculously improve angling even if the dam contains suitable indigenous angling fishes. In this way undesirable species may be introduced into systems or parts of systems.

\subsubsection{Effects on the genetics of indigenous species}

Dams create unnatural habitats for species which are adapted to riverine conditions. In the long run these environmental changes should have an effect on gene pools. From a puristic conservation viewpoint such unnatural changes should be avoided but of course such a viewpoint is unrealistic under most circumstances.

\section{Discussion}

As a result of their natural limited distributions, unstable environments and the effects of a long period of negative human influences, many Cape freshwater fishes are threatened with extinction. The most important of these negative factors are probably overgrazing, ploughing, water extraction and the introduction of exotic fish species. A host of other factors such as eutrophication, chemical pollution, mineralisation, removal or change of riverine vegetation and the results of dam or weir construction have all played a role. Fortunately hybridisation is not a factor yet but should be seriously considered in the light of the recent interest in propagating indigenous instead of foreign species.

In the past the general attitude towards freshwater fish has predominantly been that of utilization, and rarely that of preservation. Till fairly recently even conservationists seem to have considered freshwater fish as a separate "group of organisms", capable of looking after themselves, requiring little or no conservaton measures, no matter to what extent human interference was involved. In this regard, Miller (1972) points out that it is only within the past decade,especially since 1963, that these threats to the survival of many unique indigenous fish species have become widely recognized. During this time many countries, particularly in the West, have been enacting legislation and enforcing protection of endangered 
species and subspecies as well as maintaining natural habitats and creating aquatic reserves for some of the rare seriously endangered freshwater fish species.

The provincial nature conservation authorities in South Africa have followed this move. Extensive fish distribution surveys have been done in all the major river systems and the conservation of indigenous freshwater fishes feature strongly in management policies.

In the Cape Province the conservation of indigenous freshwater fishes is directed primarily towards the conservation of species in their natural habitats with maximum opportunity for genetic variation and thus allowing for normal evolutionary processes. Therefore, wherever practical, the basic aim is directed at the conservation of different "pools" of unique genetic material.

Greig (in press) defines genetic conservation as the management of a living organism in such a way as to prevent unnecessary loss of genetic variation, to protect species from introgression and unnatural hybridisation and to conserve the genetic integrity of subspecies and ecotypes by discouraging ill-considered translocations, while recognizing that the long-term conservation of life depends upon the maintenance of the rich store of genetic diversity bequeathed to us by aeons of evolution. Genetic conservation is not a new concept but it is certainly new to conservaion policies and fisheries management plans.

The management of any freshwater resource can only be effective if it is done according to a written policy which clearly spells out the guidelines for the various conservation strategies.

Just over twenty years ago Wallis (1959) mentioned that the United States National Park's management regarding indigenous fish species was directed towards: (1) The determination of original and present aquatic conditions; (2) The perpetuation and restoration of indigenous fishes, natural aquatic conditions, and associated plants and animals; (3) the creation of greater appreciation of the aquatic resources through the interpretation of these features to the park visitors.

In this regard Moyle (1976) proposes that each basin, sub-basin and stream system in California needs a management plan that is part of a state-wide plan of resource use, conservation, and management.

The Cape Department of Nature and Environmental Conservation has recently drawn up a freshwater management policy. Based on the results of this fish distribution survey, rivers and streams have been divided into the following categories:

(i) Important for the conservation of indigenous fauna and flora or unique ecosystems:

These areas will, as far as possible, be monitored and protected against negative influences such as water extraction, damming, pollution, siltation, exotics, etc. Suitable sanctuaries for each of the rare endemic fish species will be demarcated, preferably in conservation areas and managed to ensure their survival. No introduction of exotics or any species which does not occur there naturally, will be 
allowed into the catchment areas of these streams, and if exotics do occur, an attempt will be made to eliminate them.

(ii) Not of prime importance for the conservation of indigenous fish species or aquatic ecosystems:

These rivers will be managed for angling or commercial utilisation, and may be stocked with exotics.

(iii) Water which, through misuse and pollution, have become unsuitable for fish and other aquatic organisms:

Management will be aimed at the rehabilitation of these waters.

The major advantages of a written policy is that it is brought about by a group effort and consequently includes all the important concepts. For both research and management it is advantageous to work towards clearly defined objectives on which decisions will be based. For the non-professional conservationist it provides a set of well-defined guidelines.

Depending on circumstances all or some of the following measures could be implemented in fish conservation management:

(i) Public education in conservation through the use of all available media and methods. Special attention should be given to: (1) people of influence (political leaders) (2) educational institutes, and (3) the public at large, using educational aids such as television, radio, films, posters, photographic displays and well presented lectures.

The ecosystem approach should be adopted and propagated at all levels of education and the public should be made aware of the need to preserve unique aquatic ecosystems with endemic species. Accepted ecological concepts like genetic conservation and its importance should be brought home to them through the various methods of conservation education.

(ii) A serious attempt should be made to accomplish better understanding and co-operation between ecologists and engineers in future river-basin development. Efforts should be made to improve the professional status of biologists in river development schemes (Cendana 1965).

(iii) Soil and water conservation should be improved and there should be more stringent control over negative factors such as pollution, toxication, siltation, excessive water extraction, etc.

(iv) Fish translocations or introductions should only be allowed after careful scientific investigation. To prevent genetic swamping indigenous species should be restricted to their natural distribution ranges.

(v) Fish "sanctuaries" of which whole catchment areas are protected should be established for each of the threatened fish species. These sanctuaries should be managed as natural ecosystems in order to allow unaltered natural selection to continue.

(vi) Management of freshwater resources should be based on well-defined policies. A management plan in which conservation strategies are outlined must be compiled for each river system. The conservation of genetic diversity should have high priority in these strategies. 


\section{Acknowledgements}

The authors are greatly indebted to:

The Director of Nature and Environmental Conservation of the Cape Province for permission to publish this information.

Their colleagues, Messrs. D. Harper, S. McVeigh, C. Stuart, Q. Hahndiek, D. Heard and Mrs. Anne Scott who all assisted in some or other way in collecting information for this report.

The Director of the Albany Museum, Grahamstown for furnishing distribution data.

Dr. P.H. Skelton of the Albany Museum for the identification of specimens and many valuable discussions.

Dr. R.A. Jubb for reading the manuscript and for historic information, guidance and encouragement.

Mrs. L. Ashwell for typing the manuscript.

\section{REFERENCES}

ALFRED, E. R. 1968. Rare and endangered freshwater fishes of Malaya and Singapore. I.U.C.N. Publications New Series 10: 325-331.

BARNARD, K. H. 1943. Revision of the indigenous freshwater fishes of the S. W. Cape Region. Ann. S. Afr. Mus. 36(2): 101-263.

CAMBRAY, J. A. and R. A. JUBB. 1977. Dispersal of fishes via the Orange-Fish tunnel, South Africa. J. Limnol. Soc. sth. Afr., 3(1): 33-35.

CENDANA, S. M. 1965. Summary of papers and discussion of technical session III: Conservation education and training. I.U.C.N. New Publications Series 10:177-180.

CHUTTER, F. M. 1969. The effects of silt and sand on the invertebrate fauna of streams and rivers. Hydrobiologia 34:57-76.

EDWARDS, D. 1969. Some effects of siltation upon aquatic macrophyte vegetation in rivers. Hydrobiologia 34:29-37.

GAIGHER, C. M. 1973. Die status van inheemse vis in die Olifantsrivier. Research Report. C.P.A. Department of Nature Conservation.

GAIGHER, I. G. 1974. The habitat preferences of fishes from the Limpopo River System, Transvaal and Mocambique. Koedoe 16:103-116.

GAIGHER, I.G. 1975. The ecology of a minnow Barbus trevelyani (Pisces, Cyprinidae) in the Tyume River, eastern Cape. Ann Cape Prov. Mus. 11(1):1-19.

GAIGHER, I. G. 1976. Geographical variation and synonymy of the minnows Barbus anoplus and B. motebensis M. Weber, 1897. Research Report: Fish. Dept. of Nature and Environmental Conservation, C.P.A. 171-178.

GAIGHER, I. G. 1979. Overgrazing endangers fish species. Afr. Wildlife. $33(1): 41$.

GAIGHER, I. G. and R. McC. POTT. 1973. Distribution of fishes in Southern Africa. S. Afr. J. Sci. 69: 25-27. 
GREIG, J. C. (in press). The principles and problems of genetic conservation in relation to wildlife in South Africa. Department of Nature and Environmental Conservation, C.P.A.

GROENEWALD, A.A. VAN J. 1957. The results of a survey of the fish population of the Vaal River during the period April - December 1956. Progress Report. T.P.A. Department of Nature Conservation.

JUBB, R. A. 1961. The freshwater eels (Anguilla spp.) of southern Africa. An introduction to their identification and biology. Ann. Cape Prov. Mus. 1:15-48.

JUBB, R. A. 1964. Freshwater fishes and drainage basins in Southern Africa. S. Afr. J. Sci. 60: 17-21.

JUBB, R. A. 1967. Freshwater fishes of Southern Africa. Cape Town: A. A. Balkema.

MAITLAND, P. S. 1974. The conservation of freshwater fishes in the British Isles. Biol. Conserv. 6(1): 7-14.

Mc. T. COWAN, I. 1973. Vanishing species: habitat change and reconciling conflict. I.U.C.N. New Publications Series 28: 321-333.

MILLER, R. R. 1972. Threatened freshwater fishes of the United States. Trans. Am. Fish. Soc. 101(2): 239-252.

MOYLE, P. B. 1976. Fish introductions in California: history and impact on native fishes. Biol. Conserv. 9(2): 101-118.

MULDER, P. F. S. 1973. Aspects of the ecology of Labeo capensis and Labeo umbratus in the Vaal River. Zool. Afr. 8:15-24.

SKELTON, P. H. 1974. A new Barbus species (Pisces, Cyprinidae) from the Olifants River system, western Cape Province, South Africa. Spec. Publ. Rhodes Univ. Dept. Ichthyol. 13: 1-12.

SKELTON, P. H. 1977. South African Red Data Book-Fishes. S.A. National Scientific Programmes Report No. 14.

TILZEY, R. D. J. 1976. Observations on interactions between indigenous Galaxiidae and introduced Salmoniidae in the Lake Eucumbene Catchment, New South Wales. Aust. J. Mar. Freshwater Res. 27: 551-564.

VAN RENSBURG, K.J. 1966. Die vis van die Olifantsrivier (weskus) met speciale verwysing na die geelvis (Barbus capensis) en saagvin (Barbus serra). Investigational Report No. 10. Department of Nature Conservation, C.P.A. 1-14.

WALLIS, O.L. 1959. Management of sport fishing in U.S. National Parks. National Park Service, U.S. Dept. of the Interior. Typescript 9 pp. 